\title{
Group Transfer to an Aliphatic Bond: A Biomimetic Study Inspired by Nonheme Iron Halogenases
}

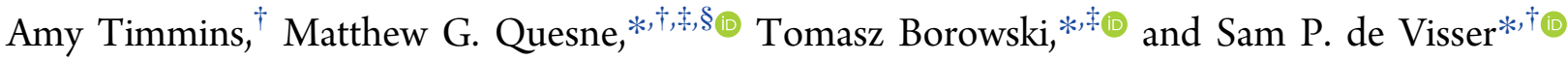 \\ ${ }^{\dagger}$ The Manchester Institute of Biotechnology and School of Chemical Engineering and Analytical Science, The University of \\ Manchester, 131 Princess Street, Manchester M1 7DN, United Kingdom \\ ${ }^{\ddagger}$ Jerzy Haber Institute of Catalysis and Surface Chemistry, Polish Academy of Sciences, Niezapominajek 8, 30-239 Krakow, Poland \\ ${ }^{\S}$ School of Chemistry, Cardiff University, Main Building, Park Place, Cardiff CF10 3AT, United Kingdom
}

\section{Supporting Information}

ABSTRACT: In this work, we predict a group-transfer reaction to an aliphatic substrate on a biomimetic nonheme iron center based on the structural and functional properties of nonheme iron halogenases. Transferring groups other than halogens to $\mathrm{C}-\mathrm{H}$ bonds on the same catalytic center would improve the versatility and applicability of nonheme iron

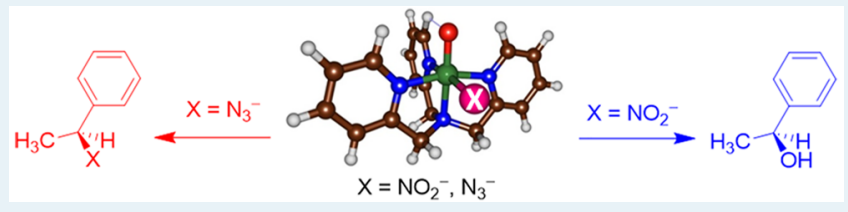
halogenases and enhance their use in biotechnology; however, few studies have been reported on this matter. Furthermore, very few biomimetic models are known that are able to transfer halogens or other groups to aliphatic $\mathrm{C}-\mathrm{H}$ bonds. To gain insight into group transfer to an aliphatic $\mathrm{C}-\mathrm{H}$ bond, we performed a detailed computational study on a biomimetic nonheme iron complex and studied the reactivity patterns with a model substrate (ethylbenzene). In particular, we investigated the reaction mechanisms of $\left[\mathrm{Fe}^{\mathrm{IV}}(\mathrm{O})(\mathrm{TPA}) \mathrm{X}\right]^{+}$, TPA $=$tris(2-pyridylmethyl)amine, and $\mathrm{X}=\mathrm{Cl}, \mathrm{NO}_{2}, \mathrm{~N}_{3}$ with ethylbenzene leading to 1phenylethanol and 1-phenyl-1-X-ethane products. Interestingly, we find that the product distributions vary with the nature of the equatorial $\mathrm{X}$-substituent on the metal center. Thus, $\left[\mathrm{Fe}^{\mathrm{IV}}(\mathrm{O})(\mathrm{TPA}) \mathrm{NO}_{2}\right]^{+}$reacts with ethylbenzene by dominant hydroxylation of the substrate, whereas with halide/azide in the cis-position a group transfer is more likely. As such, we predict a catalytic mechanism of azidation of aliphatic groups using a biomimetic nonheme iron oxidant. The results have been analyzed with thermochemical cycles, valence bond schemes and electronic assignments of reactants and products, which put our results in a broad perspective and predict the effect of other substituents. Finally, predictions are given on how these systems could be utilized in vivo.

KEYWORDS: biomimetic models, density functional theory, hydroxylation, azidation, nitration, halogenation

\section{INTRODUCTION}

In Nature, halogenases catalyze the addition of a halogen atom to a wide variety of molecular scaffolds-including aromatic and heterocyclic rings, olefinic sites, and unactivated aliphatic carbon centers. ${ }^{1}$ Indeed, more than 4500 naturally occurring halogenated compounds have been identified already. ${ }^{2}$ The halogen-transfer enzymes are subdivided into several classes, the largest being the haloperoxidases that utilize hydrogen peroxide and react on either a heme, a vanadium cofactor, or a flavin group to halogenate a variety of electron-rich carbon centers. $^{2 b, 3}$ In addition to these haloperoxidases, there is a second group of halogen-transfer enzymes, namely the $\alpha$ ketoglutarate $(\alpha \mathrm{KG})$ dependent halogenases, that react through a radical mechanism. These $\alpha \mathrm{KG}$ dependent halogenases utilize iron, $\alpha \mathrm{KG}$ as a cosubstrate, and dioxygen. Experimental studies showed the $\alpha \mathrm{KG}$-dependent halogenases to react via a rate-determining hydrogen atom abstraction from aliphatic ( $\mathrm{sp}^{3}$-hybridized) carbon atoms. ${ }^{4}$ The $\alpha \mathrm{KG}$-dependent oxidases are also an extremely diverse and useful class of biocatalysts, with members of this superfamily involved in biological pathways as varied as antibiotic biosynthesis and toxin metabolism. ${ }^{5}$
Figure 1 illustrates the active-site region of a typical $\alpha \mathrm{KG}$ dependent halogenase, namely from SyrB2, with the position of the heavy atom coordinates taken from the $2 \mathrm{FCT}$ protein data bank (pdb) file. ${ }^{6}$ SyrB2 catalyzes a key step in the biosynthesis of syringomycin, whereby a threonine amino acid (Thr) tethered to the SyrB1-S-Thr carrier protein is chlorinated at the methyl position. ${ }^{7}$ The active site contains the characteristic iron coordination motif of two histidine and one anion ( $\mathrm{Cl}$ ) occupying one face of the coordination octahedron, which is common to all known members of the $\alpha$ KG-dependent dioxygenase superfamily. ${ }^{8}$ However, while most of the closely related dioxygenases utilize a wellconserved 2His-1Asp/Glu motif to coordinate the central iron atom, by contrast, $\alpha \mathrm{KG}$-dependent halogenases lack the acidic residue, which is replaced by an alanine $\left(\mathrm{Ala}_{118}\right.$ in SyrB2), and hence have a $2 \mathrm{His}-1 \mathrm{Cl}$ ligand motif. ${ }^{9}$ It has been suggested that the structural change creates a hydrophobic

Received: April 28, 2018

Revised: July 26, 2018

Published: August 7, 2018 


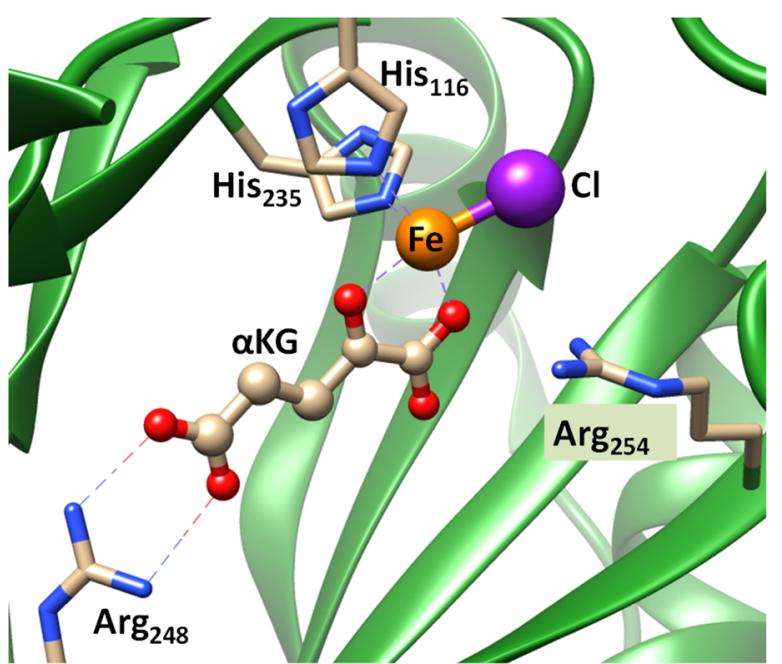

Figure 1. Active-site region of the $\alpha$ KG-dependent halogenase SyrB2 as taken from the pdb file $2 \mathrm{FCT}$. Amino acid residues are labeled according to the annotation in the pdb file.

cavity, where a halogen atom fits in and is able to coordinate the metal. ${ }^{10}$

The halogen binds in the position trans to the keto group of the cosubstrate, while the remaining ligand site of the metal is occupied by molecular oxygen, namely trans to one of the histidine residues. Oxygen binding generates an iron(III)superoxo radical capable of decarboxylating $\alpha \mathrm{KG}$ to form a highly active iron(IV)-oxo intermediate. ${ }^{11}$

Despite all of the recent progress in understanding how natural and synthetic iron(IV)-oxo catalysts are able to hydroxylate or halogenate their substrates, the philosopher's stone that would enable chemists to install a wide range of functional groups onto aliphatic carbon centers remains elusive. $^{12}$ In particular, research on the formation of $\mathrm{C}-\mathrm{N}$ products has tended to focus on the use of synthetic metalcontaining catalysts. ${ }^{13}$ Historically, iodonium azide $\left(\mathrm{IN}_{3}\right)$ has been used as a reagent to generate a $\mathrm{C}-\mathrm{N}_{3}$ linkage since radical azidation is thermodynamically favorable due to the small bond dissociation energy (BDE) of the $\mathrm{I}-\mathrm{N}_{3}(28.6 \mathrm{kcal}$ $\mathrm{mol}^{-1}$ ) through facile homolytic cleavage. Much larger BDEs of 92.1 and $80.1 \mathrm{kcal} \mathrm{mol}^{-1}$ are found for $\mathrm{H}-\mathrm{N}_{3}$ and $\mathrm{CH}_{3}-\mathrm{N}_{3}$ respectively, leading to the azidation of weak ethereal $\mathrm{C}-\mathrm{H}$ bonds. ${ }^{14}$ The combination of azidoiodinane reagents and metal catalysts allowed the transfer of $\mathrm{N}_{3}$ to tertiary and secondary $\mathrm{C}-\mathrm{H}$ bonds at much lower temperatures; ${ }^{15}$ however, when looking to develop catalysts that form $\mathrm{C}-\mathrm{N}$ bonds on a large range of unactivated carbon centers one may be inspired by Nature. A recent study by Matthews et al. ${ }^{16}$ demonstrated, for the first time, direct evidence of the nitration and azidation capabilities of $\alpha \mathrm{KG}$-dependent halogenases, whereby instead of transferring a halogen atom to an aliphatic group an $\mathrm{NO}_{2}$ or $\mathrm{N}_{3}$ radical was transferred. Unfortunately, the yields of both reaction products were very small, making industrial applications limited. As sometimes regioselectivities and product distributions are dependent on the shape and size of the substrate binding pocket of the enzymatic structure, we decided to investigate the nitration and azidation reaction using a biomimetic model complex instead.

Biomimetic models are useful chemical catalysts inspired from Nature. ${ }^{5,17}$ They are relatively small in size compared to the enzymes that inspired their design and dissolve and react in industrial solvents at room temperature. Several biomimetic model complexes that represent the active site of $\alpha \mathrm{KG}$ dependent halogenases and hydroxylases have been developed previously, including the iron-TPA model $(\mathrm{TPA}=\operatorname{tris}(2-$ pyridylmethy1)amine), Scheme $1 .{ }^{18}$ This system is well

\section{Scheme 1. Model and Chemical Reactions Investigated in} This Work

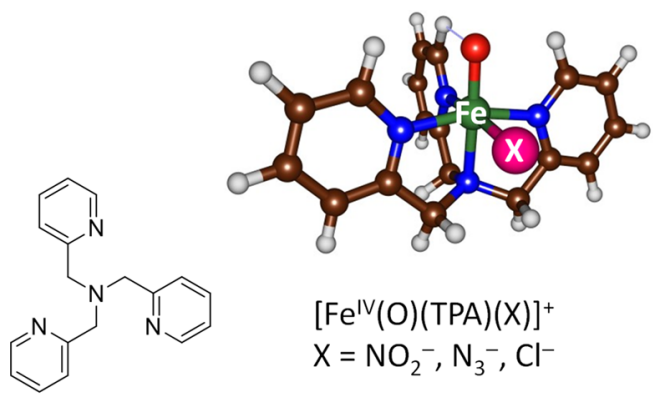

TPA

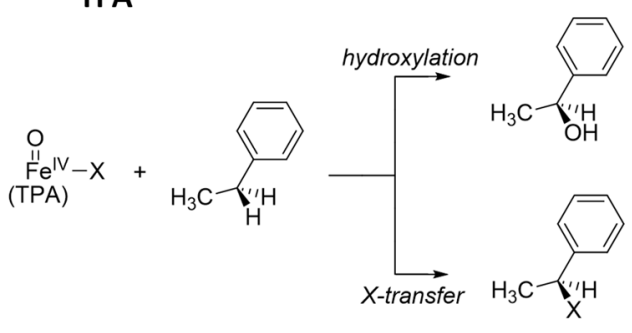

studied and has shown to react with terminal oxidants, such as $\mathrm{H}_{2} \mathrm{O}_{2}$, and reacts with substrates via aliphatic and aromatic hydroxylation and sulfoxidation. ${ }^{18}$ Furthermore, research has shown that the product distributions of the reactions are strongly dependent on the nature of the cis-ligand, i.e., group $\mathrm{X}$ in Scheme 1, and when a halogen is bound $(\mathrm{X}=\mathrm{Cl})$ some substrate halogenation is observed in line with enzymatic halogenases. ${ }^{18 a}$

Additionally, computational modeling on the chemoselectivity of aliphatic hydroxylation versus halogenation of ethylbenzene by $\left[\mathrm{Fe}^{\mathrm{IV}}(\mathrm{O})(\mathrm{TPA}) \mathrm{Cl}\right]^{+}$showed that the product distributions were dependent on the ground electronic state of the reactant, i.e., either triplet or quintet, as well as the local environment of the system. ${ }^{19}$ The question that remains is whether this system would be able to perform group-transfer reactions in general with ligands bound in the cis-position. Therefore, we decided to extend our previous studies with several reaction pathways not previously investigated for aliphatic nitration and azidation reactions. The work shows that indeed this biomimetic model complex can perform these group-transfer reactions well, but significant amounts of substrate hydroxylation byproducts may be expected. We also analyze the electronic and chemical factors that affect the bifurcation pathways and come with suggestions on how to further improve the oxidant.

\section{METHODS}

All methods and procedures reported in this work were carefully benchmarked and calibrated and are known to reproduce experimental results well. We started out with the work presented previously on the reactivity of $\left[\mathrm{Fe}^{\mathrm{IV}}(\mathrm{O})\right.$ $(\mathrm{TPA})(\mathrm{Cl})]^{+}$with substrates. ${ }^{19,20}$ All calculations used density functional theory methods as implemented in the Gaussian 09 software package. ${ }^{21}$ Structures were fully optimized without 
Scheme 2. Reaction Mechanisms Investigated in This Work with Definitions of Symbols Used in the Text

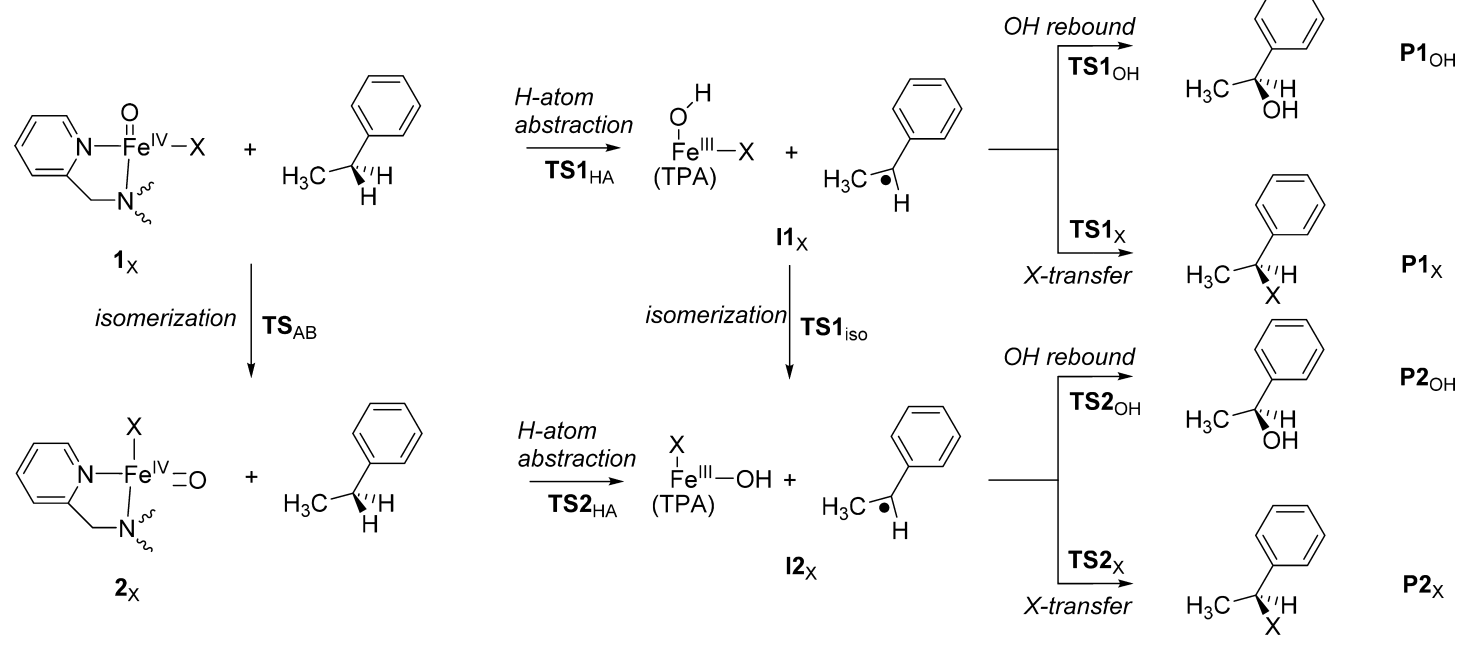

constraints using both the hybrid density functional method $\mathrm{UB} \mathrm{LYP}^{22}$ as well as the pure density functional UBP86. ${ }^{23}$ Test calculations were also performed using the hybrid metaGGA functionals $\mathrm{TPSSh}^{24}$ and $\mathrm{M06}^{25}$ which contain intermediate levels of Hartree-Fock exchange, but no major differences in the results were obtained. Initial geometry optimizations, geometry scans, and frequency calculations were done with the double- $\zeta$ quality basis set LACVP on iron (with core potential) and $6-31 \mathrm{G}$ on the rest of the atoms (BS1). ${ }^{26}$ Transition states were located by running an extensive set of geometry scans between two local minima along a specific reaction coordinate followed by full transition-state geometry optimization starting from the geometry on the maximum of these scans. For a selection of reaction pathways, intrinsic reaction coordinate optimizations were performed that confirmed the transition states as a first-order saddle point connecting the reactant and radical intermediates.

Analytical frequencies were performed for each structure and used to estimate free energies with zero-point (ZPE), thermal, entropic, and solvent $\left(E_{\text {solv }}\right)$ corrections calculated at 1 atm pressure and a temperature of $298 \mathrm{~K}$. Transition states were confirmed as first-order saddle points; they featured only one normal mode with an imaginary frequency, and this mode corresponds to the over-the-barrier motion. Final electronic energies were obtained through single-point calculations on each optimized geometry using a triple- $\zeta$ type LACV3P+* basis set on iron (with core potential) and $6-311+\mathrm{G}^{*}$ on the rest of the atoms (BS2). Implicit solvent corrections used the polarized continuum model with a dielectric constant of $\varepsilon=$ 35.688 as experimental work on biomimetic iron(IV)-oxo complexes is usually performed in acetonitrile. ${ }^{18} \mathrm{~A}$ correction for van der Waals interactions was also added using the dispersion model of Grimme as implemented in Gaussian. ${ }^{27}$ Unless otherwise indicated, all energies reported here used UB3LYP in conjunction with the BS2 basis set. To test the basis set effect, we calculated some reaction mechanisms with both UB3LYP/BS2 and UB3LYP/BS2//UB3LYP/BS1 and compared the relative energies and optimized geometries. Similarly to previous studies of analogous systems, ${ }^{28}$ we find relative energies along the landscape that are within $0.5 \mathrm{kcal}$ $\mathrm{mol}^{-1}$ of each other with analogous structures (Supporting Information). As such, the full project was run at the UB3LYP/ BS2//UB3LYP/BS1 level of theory.
Ethylbenzene was used as a model substrate since its $\mathrm{C}-\mathrm{H}$ bond dissociation energy is typical for aliphatic substrates used by halogenases. ${ }^{29}$ Finally, primary kinetic isotope effects (KIEs) were assessed by substituting the transferring hydrogen atoms with deuterium and reevaluating the free energy of activation. $^{30}$ The calculations were run for the lowest lying singlet, triplet, quintet, and septet spin state surfaces.

\section{RESULTS}

In natural halogenases and biomimetic halogenase systems, several mechanisms were proposed for the bifurcation pathways leading to substrate hydroxylation and halogenation; see Scheme 2. 11,16,19 To find out whether nitration and azidation would be possible on the same iron(IV)-oxo complex, we investigated the same reaction scheme for these processes for the reaction of ethylbenzene by $\left[\mathrm{Fe}^{\mathrm{IV}}(\mathrm{O})(\mathrm{TPA})\right.$ $(\mathrm{X})]^{+}$with $\mathrm{X}=\mathrm{NO}_{2}^{-} / \mathrm{N}_{3}^{-}$.

The reaction starts with an initial hydrogen atom abstraction from the benzyl position of ethylbenzene to form an iron(III)hydroxo complex and a radical intermediate $\left(\mathbf{I}_{\mathrm{X}}\right)$ via a transition state $\mathbf{T S} \mathbf{1}_{\mathrm{HA}}$. Three pathways starting from the radical intermediate $\mathbf{I} \mathbf{1}_{\mathrm{X}}$ were investigated, namely (i) $\mathrm{OH}$ rebound (via barrier $\mathbf{T S} \mathbf{1}_{\mathrm{OH}}$ ) to form alcohol products $\left(\mathbf{P} \mathbf{1}_{\mathrm{OH}}\right)$, (ii) X-group transfer to the radical to form product $\mathbf{P} \mathbf{1}_{\mathrm{X}}$ via a transition state $\mathbf{T S} \mathbf{1}_{\mathrm{X}}$, and (iii) isomerization from $\mathbf{I} \mathbf{1}_{\mathrm{X}}$ to $\mathbf{I} \mathbf{2}_{\mathrm{X}}$ for the interchange of the $\mathrm{OH}$ and $\mathrm{X}$ groups on the iron(III) center. Of course, the interchange of the oxo and $\mathrm{X}$ ligands can also happen on the iron(IV)-oxo reactant complex $\mathbf{1}_{\mathrm{X}}$ to give the rotated isomer $\mathbf{2}_{\mathrm{X}}$, and as such this was investigated as well. The rotated intermediate can undergo the same reactivity patterns as structure $\mathbf{I} \mathbf{1}_{\mathrm{X}}$ and performs $\mathrm{OH}$ rebound via barrier TS2 $2_{\mathrm{OH}}$ to form alcohol products $\left(\mathbf{P} \mathbf{2}_{\mathrm{OH}}\right)$ or X-transfer via barrier $\mathbf{T S} \mathbf{2}_{\mathrm{X}}$ to give $\mathbf{P} \mathbf{2}_{\mathrm{X}}$ products. Products $\mathbf{P} \mathbf{1}$ and $\mathbf{P 2}$ differ by the position of the fifth ligand to the metal. We tested the full mechanism of Scheme 2 on all available spin-state surfaces as well as in various electronic configurations. Our comprehensive and detailed study accumulated many results, which are mostly relegated to the Supporting Information, while we focus here on the major trends only.

Although the mechanism in Scheme 2 looks similar to that described and published previously on analogous systems with halide in the cis-position, actually the binding of alternative anions, i.e., $\mathrm{NO}_{2}^{-}$or $\mathrm{N}_{3}{ }^{-}$, has a major effect on the oxidation 
Scheme 3. Reactant Orbital Occupation and Electron-Transfer Processes in the Hydrogen Atom Abstraction

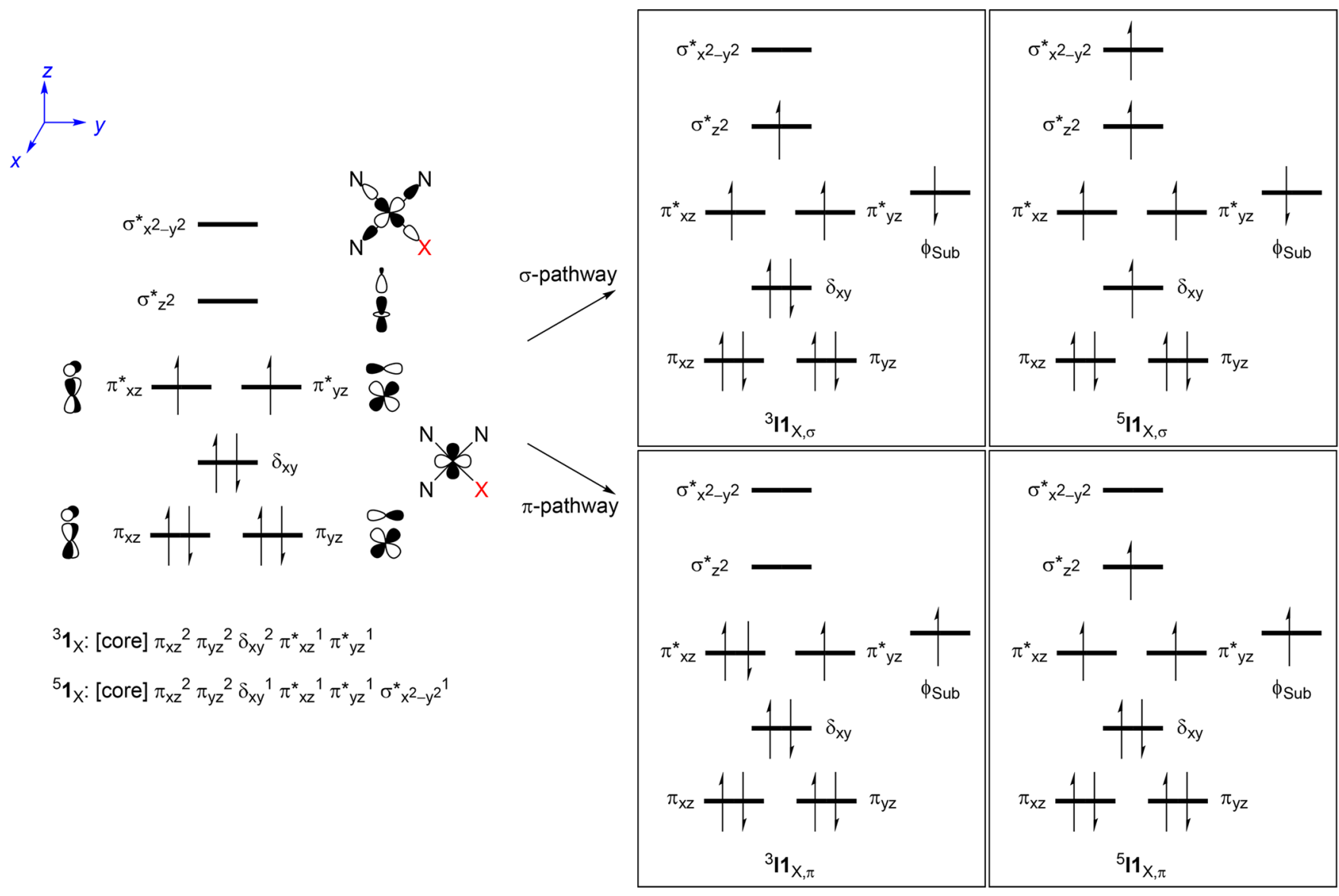

potential of the ferryl oxidant and its spin-state ordering and, thus, affects the chemoselectivities of the reaction as well as the product distributions, which requires a detailed discussion. Previous work by our group on a nonheme iron biomimetic model showed that substrate binding and orientation in the second coordination sphere could have a dramatic effect on both the availability of the preferred reaction channel as well as the rate of the reaction. ${ }^{31}$ As such, the size, shape, and electron-withdrawing/donating ability of the cis-ligand may incur structural as well as electronic effects on the reaction.

To test these competing hypotheses, an intensive theoretical study was undertaken to investigate the reaction mechanisms outlined in Scheme 2 using ethylbenzene (EB) as the substrate. Two isomers were generated for each anion in the complex $\left[\mathrm{Fe}^{\mathrm{IV}}(\mathrm{O})(\mathrm{TPA})(\mathrm{X})\right]^{+}$, where $\mathrm{X}$ is $\mathrm{NO}_{2}{ }^{-}, \mathrm{N}_{3}{ }^{-}$, or $\mathrm{Cl}^{-}$, with the oxo group either trans to the amine nitrogen (isomer $\mathrm{A} ; \mathbf{1}_{\mathrm{X}}$ ) or trans to a pyridine nitrogen (isomer $\mathrm{B} ; \mathbf{2}_{\mathrm{X}}$ ). Apart from the two isomers, nonheme iron oxidants have close-lying triplet and quintet spin states, as well as the septet and singlet spin states that lie somewhat higher in energy, and as such a multistate reactivity pattern with a mechanism and rate constant on each of the individual spin states is expected. ${ }^{32}$ Therefore, all calculations cover the two isomers in the lowest lying singlet, triplet, quintet, and septet spin states.

Scheme 3 (left hand side) shows the high-lying occupied and low-lying virtual orbitals of the iron(IV)-oxo species. Thus, the reactant state has a set of orbitals $\left(\pi / \pi^{*}\right)$ in the $x z$ and $y z$-planes for the interaction of the $3 \mathrm{~d}$ orbital on Fe with a $2 \mathrm{p}$ orbital on the oxo group that are occupied with six electrons. In addition, there is another metal $3 \mathrm{~d}$ orbital $\left(\delta_{x y}\right)$ that is nonbonding and located in the plane of the three pyridyl groups and the $\mathrm{X}$ ligand. Two high-lying orbitals for the $\sigma^{*}$ antibonding interactions in the $x y$-plane and along the $z$-axis complement the series of metal-type orbitals $\left(\sigma^{*}{ }_{x 2-y 2}\right.$ and $\left.\sigma_{z 2}^{*}\right)$.

In the triplet spin state, the iron(IV)-oxo reactant has the orbital occupation $\pi_{x z}^{2} \pi_{y z}^{2} \delta_{x y}^{2} \pi_{x z}^{*} \pi_{y z}^{*}$, whereas in the quintet spin state it is $\pi_{x z}{ }^{2} \pi_{y z}{ }^{2} \delta_{x y}{ }^{1} \pi^{*}{ }_{x z}{ }^{1} \pi^{*}{ }_{y z}^{1} \sigma^{*}{ }_{x 2-y 2}{ }^{1}$. In enzymatic nonheme iron dioxygenases, the catalytically active iron(IV)-oxo species generally has a quintet spin ground state. ${ }^{33}$ However, in biomimetic nonheme iron(IV)-oxo complexes often the triplet spin state is the ground state and the quintet spin state is higher. ${ }^{18,34}$ It was reasoned that the difference is due to a pentacoordinated iron(IV)-oxo in nonheme iron dioxygenases, whereas the metal is usually hexacoordinated in biomimetic model complexes. ${ }^{35}$ Indeed, our optimized geometries of ${ }^{3,5} \mathbf{1}_{\mathrm{X}}\left(\mathrm{X}=\mathrm{NO}_{2}{ }^{-}\right.$or $\left.\mathrm{Cl}^{-}\right)$give a triplet spin ground state followed by a quintet spin state 6.1$6.6 \mathrm{kcal} \mathrm{mol}^{-1}$ higher in energy $\left(\Delta E+\mathrm{ZPE}+E_{\text {solv }}\right.$ value $)$.

Following our previously described procedure, ${ }^{19}$ we began by optimizing $\left[\mathrm{Fe}^{\mathrm{IV}}=\mathrm{O}(\mathrm{TPA})(\mathrm{X})\right]^{+}$with the oxo group cis to three pyridine nitrogen atoms and trans to the amine group $\left(\mathbf{1}_{\mathrm{X}, \mathrm{A}}\right)$. Using $\mathrm{NO}_{2}$ as the anion, we find a triplet spin ground state with the quintet spin state higher by $4.4 \mathrm{kcal} \mathrm{mol}^{-1}(\Delta G$ $\left.+E_{\text {solv }}\right)$. At the BP86 level of theory, by contrast, the same spin state ordering is found although the energy gap is slightly larger. This is generally observed in iron(IV)-oxo complexes, where pure density functional methods stabilize lower spin states and methods with a large Hartree-Fock exchange component tend to stabilize high spin states. ${ }^{36}$ Interestingly, 


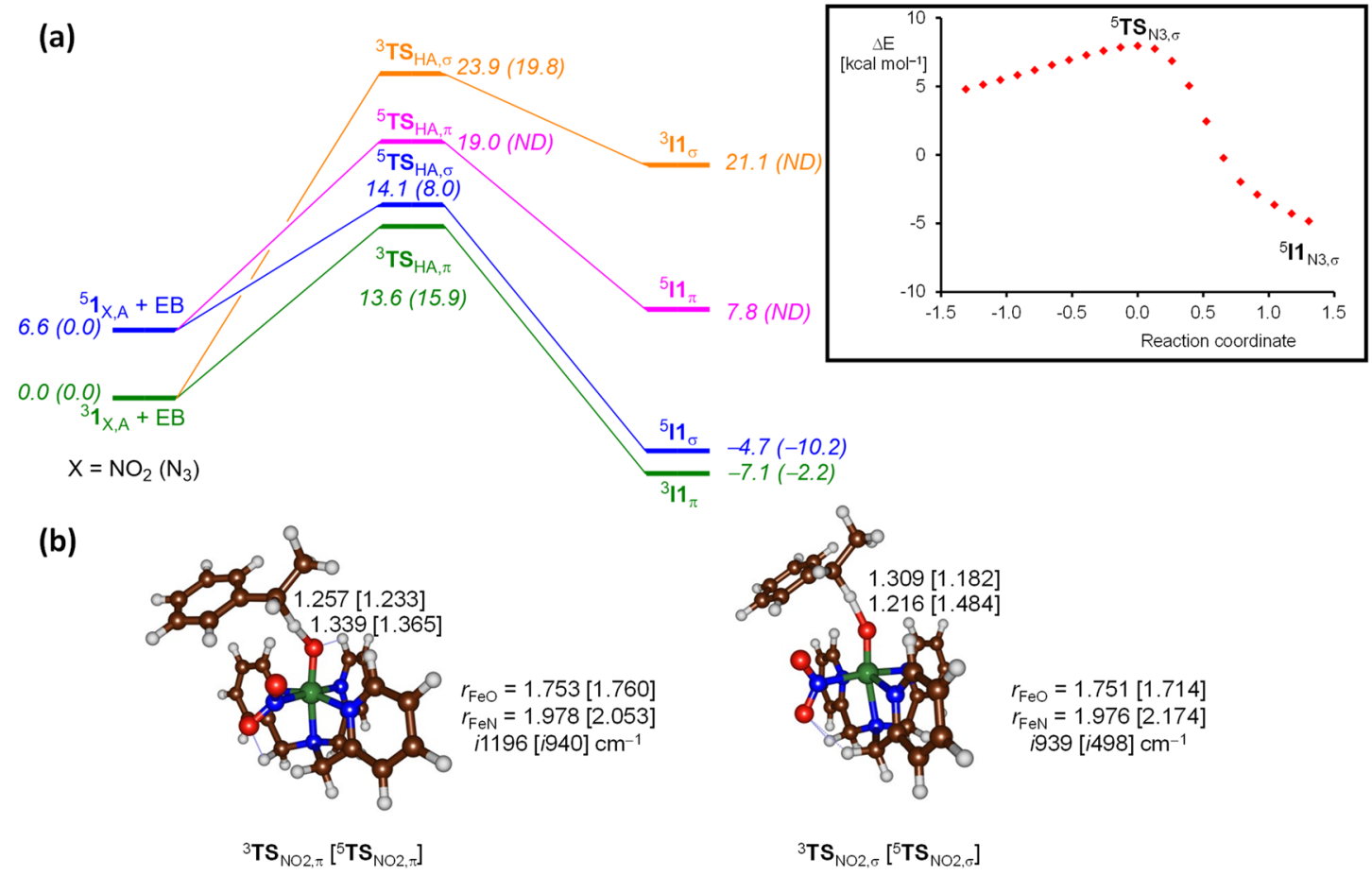

Figure 2. Hydrogen atom abstraction from the benzyl position of ethylbenzene by ${ }^{3,5} \mathbf{1}_{\mathrm{NO} 2}\left({ }^{3,5} \mathbf{1}_{\mathrm{N} 3}\right)$ leading to isomer I1. (a) Potential energy landscape with values in $\mathrm{kcal} \mathrm{mol}^{-1}$ calculated at $\Delta E+\mathrm{ZPE}+E_{\text {solv }}$ at UB3LYP/BS2//UB3LYP/BS1 in Gaussian 09. (b) Optimized geometries of hydrogen atom abstraction transition states for ${ }^{3,5} \sigma$ and ${ }^{3,5} \pi$ pathways starting from ${ }^{3,5} \mathbf{1}_{\mathrm{NO} 2}$ and ethylbenzene (EB) with bond lengths in angstroms and the imaginary frequency in wavenumbers. $\mathrm{ND}=$ not determined. (Inset) IRC profile from ${ }^{5} \mathrm{TS}_{\mathrm{N} 3, \sigma}$ as an example, which returns to reactants to the left and moves to ${ }^{5} \mathbf{I}_{\mathrm{N} 3, \sigma}$ on the right.

the effect of solvent only had a minor effect on the spin-state ordering and relative energies, and for instance, at the B3LYP/ BS2 level of theory a triplet-quintet energy gap of $6.2 \mathrm{kcal}$ $\mathrm{mol}^{-1}$ was calculated for $\mathbf{1}_{\mathrm{NO} 2}$ in the gas-phase, whereas it was raised to $6.6 \mathrm{kcal} \mathrm{mol}^{-1}$ in solvent. Our value compares very well to the spin state splitting of $6.1 \mathrm{kcal} \mathrm{mol}^{-1}$, previously reported for $\left[\mathrm{Fe}^{\mathrm{IV}}=\mathrm{O}(\mathrm{Cl})(\mathrm{TPA})\right]^{+}{ }^{19}$ interestingly, we observe closely degenerate triplet and quintet spin states when $\mathrm{N}_{3}$ is coordinated to the iron(IV)-oxo center. The decrease of the spin state energy gap, is related to the destabilization of the $\delta_{x y}$ orbital and stabilization of the $\sigma^{*}{ }_{x 2-y 2}$ orbital in the system with $\mathrm{X}=\mathrm{N}_{3}{ }^{-}$. Generally, a smaller $\delta_{x y}-\sigma^{*}{ }_{x 2-y 2}$ orbital energy gap will stabilize the quintet spin state over the triplet spin state. ${ }^{37}$ As such, the $\mathrm{N}_{3}{ }^{-}$ligand is a weaker electron donor and lowers the $\sigma_{x 2-y 2}^{*}$ orbital over that found for $\mathrm{X}=\mathrm{NO}_{2}{ }^{-}$. Indeed, the electron affinity of $\mathrm{N}_{3}$ was shown to be considerably larger than that of $\mathrm{NO}_{2}{ }^{38}$

Although there is no experimental data on the ground state $\left[\mathrm{Fe}^{\mathrm{IV}}(\mathrm{O})(\mathrm{TPA})(\mathrm{X})\right]^{+}\left(\mathrm{X}=\mathrm{NO}_{2}^{-} / \mathrm{N}_{3}^{-}\right)$species, Mössbauer spectroscopy and EXAFS (extended X-ray absorption finestructure) methods strongly indicate a ground-state triplet when the chloride anion is present. ${ }^{39}$ In all cases, we find that the singlet and septet spin states are higher in energy, and therefore, those results are relegated to the Supporting Information.

Hydrogen Atom Abstraction. The hydrogen atom abstraction from the substrate by the oxidant to form an iron(III)-hydroxo complex $\left(\mathbf{I}_{\mathrm{X}}\right)$ is accomplished with an electron transfer into the metal d-block orbitals that is different on each of the individual spin states. The hydrogen atom abstraction from the substrate rearranges some of the molecular orbitals and an extra electron is promoted into the metal d-block, while a substrate radical (in orbital $\phi_{\text {Sub }}$ ) remains. In the triplet spin state, this electron transfer can add a second electron to the $\pi^{*}{ }_{x z}$ orbital $\left({ }^{3} \pi\right.$-pathway) or alternatively fill the $\sigma_{z 2}^{*}$ orbital with one electron $\left({ }^{3} \sigma\right.$ pathway). Similarly, on the quintet spin state during the hydrogen atom abstraction an electron can fill the $\sigma_{z 2}^{*}$ orbital $\left({ }^{5} \sigma\right.$-pathway) or pair up with the $\delta_{x y}$ electron $\left({ }^{5} \pi\right.$-pathway). The ordering and the relative energies of these four hydrogen atom abstraction pathways are dependent on several variables, such as the structure of the oxidant, the nature of the orbital splitting, the electron-donating effect of ligand $\mathrm{X}$ and environmental perturbations. ${ }^{40}$ As such, we characterized hydrogen atom abstraction transition states and iron(III)hydroxo complexes corresponding to each of the four electrontransfer processes in Scheme 3.

The hydrogen atom abstraction of the benzyl position of ethylbenzene by ${ }^{3,5} \mathbf{1}_{\mathrm{X}}\left(\mathrm{X}=\mathrm{NO}_{2}{ }^{-}, \mathrm{N}_{3}{ }^{-}, \mathrm{Cl}^{-}\right)$was investigated on the ${ }^{3,5} \pi$ and ${ }^{3,5} \sigma$-pathways as described in Scheme 3 above. Figure 2 displays the calculated hydrogen atom abstraction step from ethylbenzene by $\mathbf{1}_{\mathrm{X}}, \mathrm{X}=\mathrm{NO}_{2}{ }^{-}$, for all four hydrogen atom abstraction pathways ( $\sigma$ and $\pi$-pathways on the triplet and quintet spin states). For $\mathrm{X}=\mathrm{NO}_{2}$, the lowest lying hydrogen atom abstraction barriers are ${ }^{3} \mathbf{T S}_{\mathrm{HA}, \mathrm{NO} 2, \pi}$ and ${ }^{5} \mathrm{TS}_{\mathrm{HA}, \mathrm{NO} 2, \sigma}$ with values of 13.6 and $14.1 \mathrm{kcal} \mathrm{mol}^{-1}$, respectively. Well above ${ }^{3} \mathbf{T S}_{\mathrm{HA}, \mathrm{NO} 2, \pi}$ in energy are ${ }^{5} \mathbf{T S}_{\mathrm{HA}, \mathrm{NO} 2, \pi}$ (by $5.4 \mathrm{kcal} \mathrm{mol}^{-1}$ ) and ${ }^{3} \mathrm{TS}_{\mathrm{HA}, \mathrm{NO} 2, \sigma}\left(\right.$ by $10.3 \mathrm{kcal} \mathrm{mol}^{-1}$ ), and consequently, these two pathways will contribute little to the reaction mechanism. The ordering of these ${ }^{3,5} \sigma$ and ${ }^{3,5} \pi$ transition states is in line with previous hydrogen atom abstraction barriers characterized for analogous systems. ${ }^{32 \mathrm{~b}, 41}$ Furthermore, it implies a two-state reactivity pattern on 
competing triplet and quintet spin states via a rate determining ${ }^{3} \mathrm{TS}_{\mathrm{HA}, \pi, \mathrm{NO} 2}$ or ${ }^{5} \mathrm{TS}_{\mathrm{HA}, \sigma, \mathrm{NO} 2}$ barrier.

Optimized geometries of the ${ }^{3,5} \sigma$ and ${ }^{3,5} \pi$ hydrogen atom abstraction transition states for the reaction of ${ }^{3,5} \mathbf{1}_{\mathrm{NO} 2}$ with ethylbenzene are shown at the bottom of Figure 2. Geometrically, the two $\pi$-pathway transition states are very much alike with similar bond lengths and angles due to analogies in electron-transfer processes taking place. Much larger geometric differences are observed between the $\pi$ - and $\sigma$-pathway transition states, which was reasoned previously to originate from the electron transfer into $\pi^{*}$ versus $\sigma^{*}{ }_{\mathrm{z} 2}{ }^{42}$ Thus, the substrate attacks sideways in ${ }^{3} \mathbf{T S}_{\mathrm{HA}, \mathrm{NO} 2, \pi}$ with an $\mathrm{Fe}-\mathrm{O}-\mathrm{H}$ angle of only $126^{\circ}$, whereas in ${ }^{5} \mathrm{TS}_{\mathrm{HA}, \mathrm{NO}, \sigma}$ the substrate attacks from the top and the $\mathrm{Fe}-\mathrm{O}-\mathrm{H}$ angle is much larger $\left(154^{\circ}\right)$.

The imaginary frequencies associated with the four hydrogen atom abstraction transition states vary somewhat and values of i1196, i940, i939, and i498 $\mathrm{cm}^{-1}$ are obtained for ${ }^{3} \mathbf{T S}_{\mathrm{HA}, \mathrm{NO} 2, \pi},{ }^{5} \mathbf{T S}_{\mathrm{HA}, \mathrm{NO} 2, \pi},{ }^{3} \mathbf{T S}_{\mathrm{HA}, \mathrm{NO} 2, \sigma}$, and ${ }^{5} \mathbf{T S}_{\mathrm{HA}, \mathrm{NO} 2, \sigma}$. Hydrogen atom abstraction steps generally are associated with sharp and narrow barriers, and hence, relatively large imaginary frequencies are seen with magnitudes well over i1000 $\mathrm{cm}^{-1}$. 43 The values observed here, therefore, and in particular the one for ${ }^{5} \mathbf{T S}_{\mathrm{HA}, \mathrm{NO}, \sigma}$ are small, which may have to do with the fact the TS is early on the potential energy surface, i.e. short $\mathrm{C}-\mathrm{H}$ and long $\mathrm{O}-\mathrm{H}$ bond lengths.

The transition-state ordering in the oxidants coordinated by $\mathrm{NO}_{2}{ }^{-}$is sharply contrasted by the ordering found when either $\mathrm{N}_{3}{ }^{-}$or $\mathrm{Cl}^{-}$is used. In particular, ${ }^{5} \mathrm{TS}_{\mathrm{HA}, \mathrm{N} 3, \sigma}$ is much lower in energy than ${ }^{3} \mathrm{TS}_{\mathrm{HA}, \mathrm{N} 3, \pi}$, by $\sim 10 \mathrm{kcal} \mathrm{mol}^{-1}$, so that the reactivity will take place on a dominant quintet spin surface and the triplet spin state will play a role of little importance. This is similar to the results reported for $\mathrm{X}=\mathrm{Cl}$ previously where the lowest lying hydrogen atom abstraction transition state was on the quintet spin state surface. ${ }^{19}$ As the reactant iron(IV)-oxo complexes with $\mathrm{N}_{3}^{-}$have degenerate quintet and triplet spin states, the quintet spin state will be populated in the reactant mixture and the spin-state crossing will be facile.

Isomerization of Iron(IV)-Oxo Complexes. In principle, there are two possible stereoisomers of the reactive species, whereby, the oxo group can be either trans or cis to the central amine group, i.e., structures $\mathbf{1}_{\mathrm{X}}$ and $\mathbf{2}_{\mathrm{X}}$, respectively. Therefore, we investigated the relative energies of each isomer as well as locating the relevant isomerization barriers, associated with ligand switching. Similarly to what was reported above, the spin state ordering of ${ }^{3,5} \mathbf{2}_{\mathrm{X}}$ is dependent on the electronic properties of group $\mathrm{X}$, whereby we observe a triplet spin ground state when $\mathrm{X}=\mathrm{Cl}^{-} / \mathrm{NO}_{2}{ }^{-}$and a quintet spin ground state when $\mathrm{X}=\mathrm{N}_{3}^{-}$(Supporting Information, Tables $\mathrm{S} 4$ and S8). These spin-state orderings and relative energy profiles are analogous to previous studies of biomimetic nonheme iron complexes, ${ }^{19,20,39,40}$ and there is remarkable consistency between the isomers of each species. In all cases, the ground-state structures of $\mathbf{1}_{\mathrm{X}}$ and $\mathbf{2}_{\mathrm{X}}$ are close in energy and could be in thermodynamic equilibrium.

Next, we investigated the potential isomerization steps, by which a rotation around the metal center could lead to the swapping of the oxo and anion coordination positions via the transition state $\mathrm{TS}_{\mathrm{AB}}$. Exploratory scans were performed from the ${ }^{3,5} \mathbf{1}_{\mathrm{X}}$ isomers through a relaxed geometry scan with fixed $\mathrm{O}-\mathrm{Fe}-\mathrm{N}_{\text {axial }}$ angles in incremental steps from $180^{\circ}$ to $90^{\circ}$, using a step size of $-5^{\circ}$. Subsequently, the maximum points along these trajectories were used to locate the rotational barriers via full transition-state optimizations; see Figure 3.

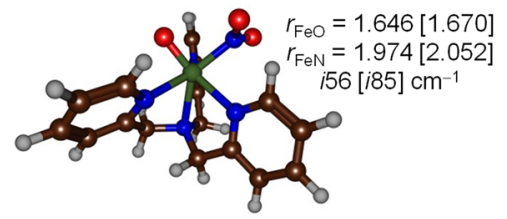

$\Delta \mathrm{E}+\mathrm{ZPE}=30.1[12.4]$

${ }^{3} \mathrm{TS}_{\mathrm{AB}, \mathrm{NO} 2}\left[{ }^{5} \mathrm{TS}_{\mathrm{AB}, \mathrm{NO} 2}\right]$

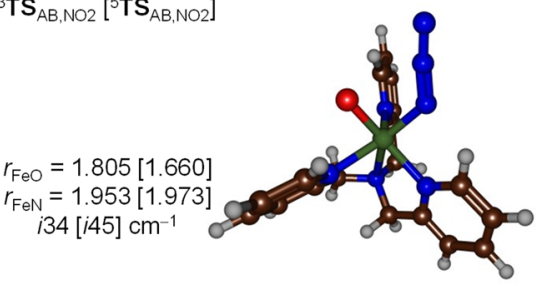

$\Delta \mathrm{E}+\mathrm{ZPE}=30.3[20.1]$

${ }^{3} \mathrm{TS}_{\mathrm{AB}, \mathrm{N} 3}\left[{ }^{5} \mathrm{TS}_{\mathrm{AB}, \mathrm{N} 3}\right]$

Figure 3. Optimized geometries of the isomerization transition states ${ }^{3,5} \mathrm{TS}_{\mathrm{AB}, \mathrm{X}}$ for $\mathrm{X}=\mathrm{N}_{3}$ and $\mathrm{NO}_{2}$. Bond lengths are in angstroms and the imaginary frequencies in wavenumbers.

Again, the $\mathrm{X}=\mathrm{Cl}^{-}$and $\mathrm{X}=\mathrm{NO}_{2}{ }^{-}$show remarkably similar $\mathbf{T S}_{\mathrm{AB}}$ energies of approximately $12.4 \mathrm{kcal} \mathrm{mol}^{-1}$, with a much higher barrier of $20.1 \mathrm{kcal} \mathrm{mol}^{-1}$ being found for the $\mathrm{TS}_{\mathrm{AB}, \mathrm{N} 3}$ in the quintet spin state. Therefore, while our results indicate the possibility that some rotation could be observed in $\left[\mathrm{Fe}^{\mathrm{IV}}(\mathrm{O})\right.$ (TPA) $(\mathrm{X})]^{+}$, with $\mathrm{X}=\mathrm{Cl}^{-} / \mathrm{NO}_{2}^{-}$; we would not expect an isomerization for $\mathrm{X}=\mathrm{N}_{3}{ }^{-}$. Analysis of the imaginary frequency modes of all three transition states indicate broad and flat potential energy surfaces; with ${ }^{5} \mathrm{TS}_{\mathrm{AB}}$ frequencies of i56.7, i45.1, and $\mathrm{i} 39.7 \mathrm{~cm}^{-1}$ for $\mathrm{X}=\mathrm{Cl}, \mathrm{N}_{3}$, and $\mathrm{NO}_{2}$, respectively.

We also investigated the hydrogen atom abstraction pathways of ethylbenzene for the isomeric structures ${ }^{3,5} \mathbf{2}_{\mathrm{NO} 2}$ on the ${ }^{3,5} \pi$ and ${ }^{3,5} \sigma$-pathways via transition state $\mathbf{T S} 2_{\mathrm{HA}, \mathrm{NO} 2}$ to form the radical intermediates $\mathbf{I} \mathbf{2}_{\mathrm{NO} 2}$. Figure 4 displays the potential energy landscape for the hydrogen atom abstraction from ${ }^{3,5} \boldsymbol{2}_{\mathrm{NO} 2}$ on the ${ }^{3,5} \pi$ and ${ }^{3,5} \boldsymbol{\sigma}$-pathways. Interestingly, the relative energies of the various ${ }^{3,5} \sigma$ and ${ }^{3,5} \pi$ transition states and radical intermediates are within $1 \mathrm{kcal} \mathrm{mol}^{-1}$ from those given above in Figure 2. The only difference appears to be a slight destabilization of the ${ }^{3} \pi$ transition state, which is raised above the ${ }^{5} \sigma$ transition state. But this change may not be significant.

The low-lying ${ }^{5} \mathbf{T S} 2_{\mathrm{HA}, \mathrm{NO} 2, \sigma}$ structure has the oxygen atoms of $\mathrm{NO}_{2}$ lying in the plane of the amine and oxo groups of the catalyst with an $\mathrm{N}-\mathrm{Fe}-\mathrm{N}-\mathrm{O}$ dihedral of $165^{\circ}$. However, in ${ }^{5} \mathbf{T S} \mathbf{2}_{\mathrm{HA}, \mathrm{NO} 2, \pi}$, the oxygen atom is in close proximity to the iron(IV)-oxo and is forced downward by a rotation around the central $\mathrm{Fe}-\mathrm{N}$ axis to give a $\mathrm{N}-\mathrm{Fe}-\mathrm{N}-\mathrm{O}$ dihedral of $136^{\circ}$ (Figure 4). Therefore, unlike other fully coordinated nonheme catalysts, there appears to be enough room for hydrogen atom abstraction via the $\pi$-channel when $\mathrm{X}=\mathrm{Cl}^{-} / \mathrm{N}_{3}{ }^{-}$is positioned in the equatorial position. However, the bulky $\mathrm{NO}_{2}{ }^{-}$group in the cis position gives an oxidant akin to a standard nonheme iron oxidant that prevents approach of substrate under the ideal geometry for the transfer of a $\beta$-electron into the $\delta_{x y}$ orbital. Importantly, when the $\mathrm{NO}_{2}$ binds to iron through the oxygen, the group is positioned in such a way as to completely block access to the ${ }^{5} \mathbf{T S} 2_{\mathrm{HA}, \mathrm{NO} 2, \pi}$. Accordingly, ${ }^{5} \mathbf{T S} \mathbf{2}_{\mathrm{HA}, \mathrm{NO}, \sigma}$ becomes the lowest energy barrier for the reaction of ethylbenzene with $\mathbf{2}_{\mathrm{NO} 2}$ (see Tables S25-S28, Supporting 

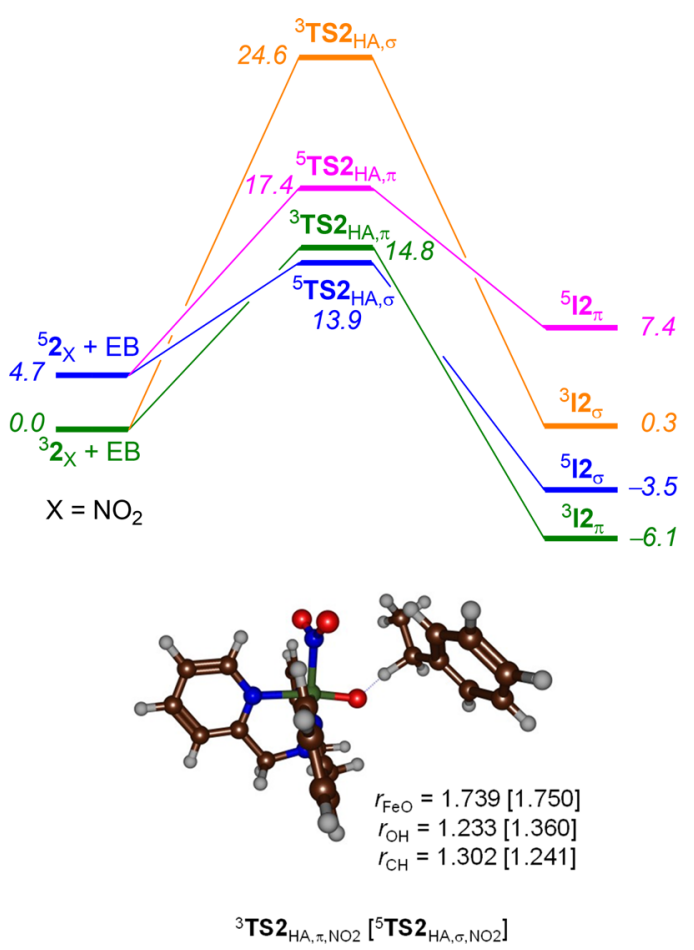

Figure 4. Hydrogen atom abstraction from the benzyl position of ethylbenzene by ${ }^{3,5} \mathbf{2}_{\mathrm{NO} 2}$. Potential energy landscape with values in kcal $\mathrm{mol}^{-1}$ calculated at $\Delta E+\mathrm{ZPE}+E_{\text {solv }}$ at UB3LYP/BS2// UB3LYP/BS1 in Gaussian 09.

Information). These steric constraints are absent in $\mathbf{1}_{\mathrm{X}} / \mathbf{2}_{\mathrm{X}}$ with $\mathrm{X}=\mathrm{Cl} / \mathrm{N}_{3}$; hence, the $\pi$-pathway is stabilized although not enough for $X=N_{3}$ to make it the lowest energy pathway.

Nitration, Azidation, Halogenation, and Hydroxylation. We proceeded from our lowest lying iron(III)-hydroxo complexes $\left(\mathbf{I} \mathbf{1}_{\mathrm{X}}\right.$ and $\left.\mathbf{I} \mathbf{2}_{\mathrm{X}}\right)$ to investigate each potential rebound process leading to hydroxylation and nitration products. Figure 5 gives the relative energies of $\mathrm{OH}$ versus $\mathrm{X}$ rebound from ${ }^{3,5} \mathrm{I} \mathbf{1}$ structures. For the $\mathrm{NO}_{2}{ }^{-}$-ligated system, ${ }^{5} \mathbf{I}_{\mathrm{NO} 2}$ gave a hydroxyl-rebound barrier of $2.0 \mathrm{kcal} \mathrm{mol}^{-1}$ in solvent, whereas the nitration barrier $\left({ }^{5} \mathbf{T S} 1_{\mathrm{X}, \mathrm{NO} 2}\right)$ was higher in energy at 5.8 $\mathrm{kcal} \mathrm{mol}^{-1}$. These patterns are repeated starting from ${ }^{5} \mathbf{I}_{\mathrm{NO} 2}$, where rebound barriers of ${ }^{5} \mathbf{T S} 2_{\mathrm{OH}, \mathrm{NO} 2}$ and ${ }^{5} \mathbf{T S} 2_{\mathrm{X}, \mathrm{NO} 2}$ of 4.2 and $6.7 \mathrm{kcal} \mathrm{mol}^{-1}$, respectively, are found. Our results indicate that both $\mathbf{I}_{\mathrm{NO} 2}$ and $\mathbf{I} \mathbf{2}_{\mathrm{NO} 2}$ will give dominant substrate hydroxylation as reaction products. Furthermore, isomerization from $\mathbf{I} \mathbf{1}_{\mathrm{NO} 2}$ to $\mathbf{I} \mathbf{2}_{\mathrm{NO} 2}$ and their equilibration will not give a major change in product distributions.

By contrast to the mechanism seen for $\mathrm{X}=\mathrm{NO}_{2}$, the rebound processes starting from ${ }^{3,5} \mathbf{I}_{\mathrm{N} 3}$ give a preference for the nitrogenous product, where the $\mathrm{N}_{3}$-transfer reaction $\left({ }^{5} \mathrm{TS} \mathbf{1}_{\mathrm{X}, \mathrm{N} 3}\right)$ is almost barrierless (Figure 5). In particular, the ${ }^{5} \mathrm{TS} 1_{\mathrm{X}, \mathrm{N} 3}$ structure for $\mathrm{X}=\mathrm{N}_{3}$ could not be located as it was too close in energy to the radical intermediate ${ }^{5} \mathbf{I}_{\mathrm{N} 3}$, and all attempts to optimize its structure failed. As such, we estimated its energy from the geometry scan connecting ${ }^{5} \mathbf{I}_{\mathrm{N} 3}$ with products ${ }^{5} \mathbf{P} \mathbf{1}_{\mathrm{N} 3}$ (Supporting Information, Figure S5). At the UB3LYP/BS2 level of theory, however, we did manage to optimize the structure of ${ }^{5} \mathrm{TS}_{\mathrm{N} 3, \mathrm{~N} 3}$, but also at this level of theory it is only $1 \mathrm{kcal} \mathrm{mol}^{-1}$ above the energy of ${ }^{5} \mathrm{I}_{\mathrm{N} 3}$. These energies match the values estimated from the geometry scan well.

Conversely, the $\mathrm{OH}$-rebound barrier starting from the same intermediate is $4.7 \mathrm{kcal} \mathrm{mol}^{-1}$ in solvent. This trend is repeated with isomer ${ }^{5} \mathbf{I} \mathbf{2}_{\mathrm{N} 3}$ that also gives a lower lying ${ }^{5} \mathbf{T S} \mathbf{2}_{\mathrm{X}, \mathrm{N} 3}$ barrier with respect to ${ }^{5} \mathbf{T S} 2_{\mathrm{OH}, \mathrm{N} 3}$. As such, binding of azide at the cisposition of $\left[\mathrm{Fe}^{\mathrm{IV}}(\mathrm{O})(\mathrm{TPA}) \mathrm{X}\right]^{+}$gives a different chemoselectivity for product formation than the reaction with $\mathrm{NO}_{2}$ in the cis-position. The pattern seen for $\left[\mathrm{Fe}^{\mathrm{IV}}(\mathrm{O})(\mathrm{TPA}) \mathrm{N}_{3}\right]^{+}$ match those previously reported for the reaction of $\left[\mathrm{Fe}^{\mathrm{IV}}(\mathrm{O})\right.$ (TPA) $\mathrm{Cl}]^{+}$with ethylbenzene, although the $\mathrm{N}_{3}$-transfer barriers are much lower in energy than halide transfer. ${ }^{19}$

Interestingly, this dominance for the alcohol production is only seen when the nitrogen atom is coordinated to the iron center in $\left[\mathrm{Fe}^{\mathrm{IV}}(\mathrm{O})(\mathrm{TPA}) \mathrm{NO}_{2}\right]^{+}$. Thus, we calculated the full reaction mechanism of ethylbenzene activation by $\left[\mathrm{Fe}^{\mathrm{IV}}(\mathrm{O})\right.$ (TPA) $\left.\mathrm{NO}_{2}\right]^{+}$with either an $\mathrm{N}$-bound $\mathrm{NO}_{2}$ group $(3,51)$ or an O-bound $\mathrm{NO}_{2}$ (structures ${ }^{3,5} 1^{*}$ ); see Figure 6. For both sets of oxidants we calculated the hydrogen atom abstraction from ethylbenzene followed by $\mathrm{NO}_{2}$ and $\mathrm{OH}$ rebound to form 1-

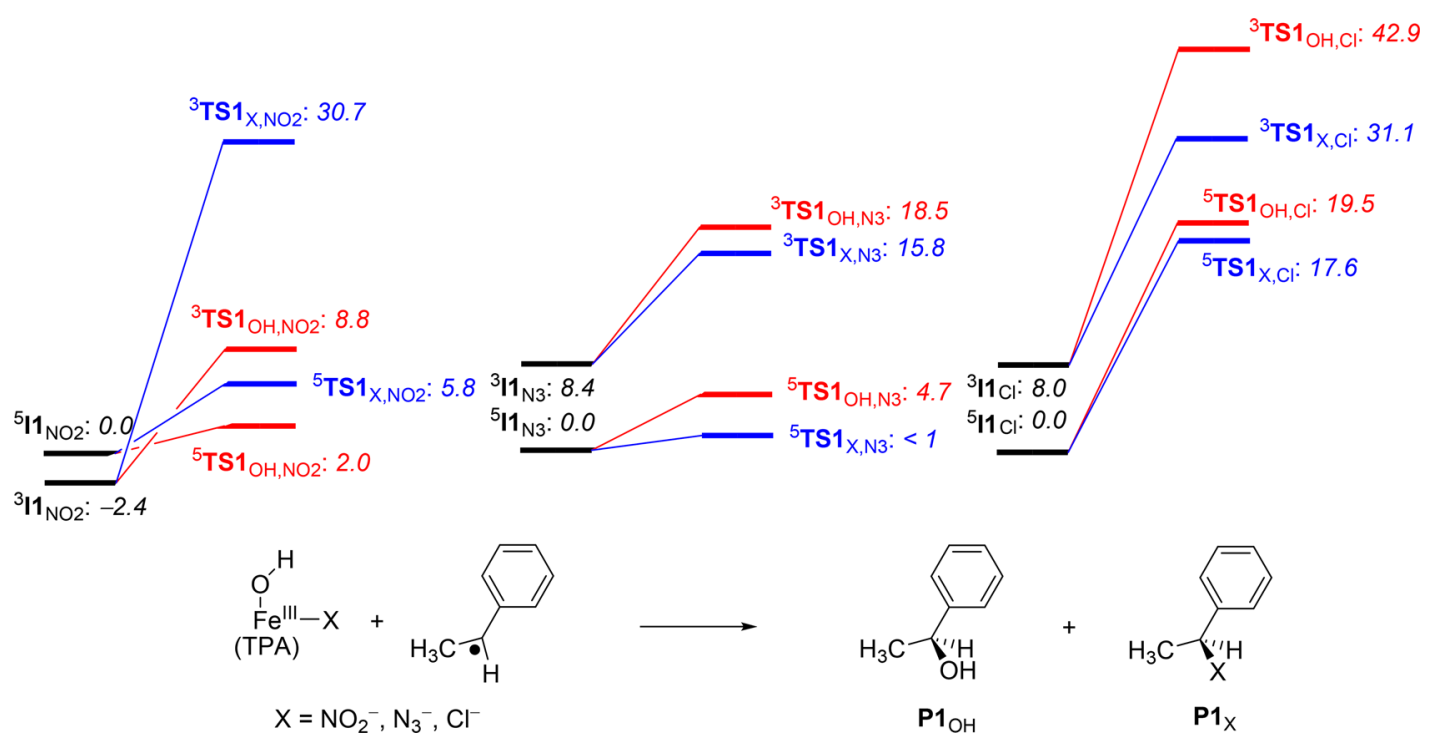

Figure 5. Group transfer to the radical by ${ }^{3,5} \mathrm{I1}_{\mathrm{X}}$. Potential energy landscape with values in $\mathrm{kcal} \mathrm{mol}^{-1}$ calculated at $\Delta E+\mathrm{ZPE}+E_{\text {solv }}$ at UB3LYP/ $\mathrm{BS} 2 / / \mathrm{UB} 3 \mathrm{LYP} / \mathrm{BS} 1$ in Gaussian 09. Energies relative to ${ }^{5} \mathbf{I}_{\mathrm{X}}$. 


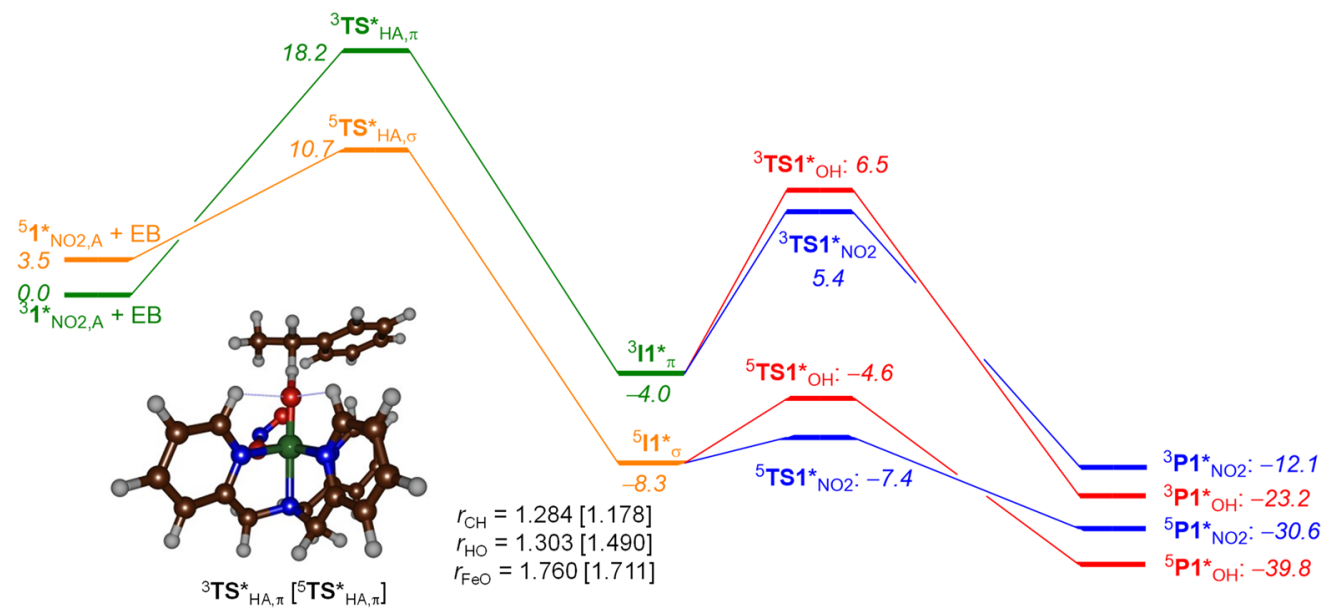

Figure 6. Potential energy surface of hydrogen atom abstraction from the benzyl position of ethylbenzene by ${ }^{3,5} 1^{*}{ }_{\mathrm{NO} 2}$ followed by $\mathrm{NO}_{2} / \mathrm{OH}$ rebound to form products. Energies are given in $\mathrm{kcal} \mathrm{mol}^{-1}$ and are calculated at the $\Delta E+\mathrm{ZPE}+E_{\text {solv }}$ level of theory at UB3LYP/BS2//UB3LYP/ BS1 in Gaussian 09. Optimized geometries of hydrogen atom abstraction transition states for ${ }^{3,5} \sigma$ and ${ }^{3,5} \pi$-pathways starting from ${ }^{3,5} 1^{*}{ }_{\mathrm{NO} 2}$ and ethylbenzene (EB) with given bond lengths in angstroms.

nitro-1-phenylethane and 1-phenyl-1-ethanol products. In addition, we calculated the isomerization of the $\mathrm{NO}_{2}$ and $\mathrm{OH}$ groups to form structures ${ }^{3,5} 2^{*}$ and their rebound processes. Figure 6 displays the mechanism obtained for the reaction of ethylbenzene with ${ }^{3,5} 1^{*}$. Although the reactant triplet spin state is the ground state, the hydrogen atom abstraction barrier on the quintet spin state is well lower than that found for the triplet spin state: $10.7 \mathrm{vs} 18.2 \mathrm{kcal} \mathrm{mol}^{-1}$. In analogy with the work reported above the barrier in the triplet spin state is of ${ }^{3} \mathbf{T S}_{\mathrm{HA}, \pi}$ type, whereas the quintet spin barrier is of ${ }^{5} \mathrm{TS}_{\mathrm{HA}, \sigma}$ type. Therefore, the triplet-quintet splitting is enlarged with oxygen coordination and the quintet spin pathway is the lowest in energy. Moreover, the barriers are competitive with those seen in Figure 2 above and hence we can expect multistate reactivity patterns through several isomeric structures on close-lying electronic and spin state surfaces. Structurally, the transition states look similar to those reported above.

For the rebound process, the nitrogenous product is favored over substrate hydroxylation on both the triplet and quintet spin states for ${ }^{3,5} 1^{*}$ as an oxidant. Note that these structures are isoenergetic to those described above in Figure 2, where the nitrogen atom binds to iron and hence they may be in equilibrium where both isomers exist next to each other. On both the triplet and quintet spin state surfaces the $\mathrm{NO}_{2}$ rebound pathway is favored over $\mathrm{OH}$ rebound, which implies that little alcohol products can be expected. As such, oxidants ${ }^{3,5} \mathbf{1}_{\mathrm{NO} 2}$ and ${ }^{3,5} \mathbf{1}^{*}{ }_{\mathrm{NO} 2}$ are expected to give different products in a reaction with ethylbenzene, whereby ${ }^{3,5} \mathbf{1}_{\mathrm{NO} 2}$ gives 1-phenyl-1ethanol as the dominant product, whereas 1-phenyl-1-nitroethane is expected from a reaction of ${ }^{3,5} 1 *{ }_{\mathrm{NO} 2}$. The energies of the individual isomers are close and therefore in experiment a mixture of oxidants is expected, resulting then in a mixture of products from the reaction with substrate.

Isomerization of Iron(III)-Hydroxo. Even though the chemoselectivity preference of the reaction starting from ${ }^{3,5} \mathbf{I} \mathbf{1}_{\mathrm{X}}$ appears to be similar to that of ${ }^{3,5} \mathbf{I} \mathbf{2}_{\mathrm{X}}$, we did for completeness calculate their isomerization barriers $\mathbf{T S} \mathbf{1}_{\text {iso }}$. Geometry scans were conducted following a protocol similar to that reported above for the $\mathrm{TS}_{\mathrm{AB}}$; however, now the $\mathrm{HO}-\mathrm{Fe}-\mathrm{N}_{\text {axial }}$ angle was varied. We calculated isomerization barriers from ${ }^{5} \mathbf{I} \mathbf{1}_{\mathrm{X}}$ to ${ }^{5} \mathbf{I} \mathbf{2}_{\mathrm{X}}$ of 15.9, 15.9, and 17.2 kcal mol${ }^{-1}$ for $\mathrm{X}=\mathrm{NO}_{2}, \mathrm{~N}_{3}$, and $\mathrm{Cl}$, respectively (see the Supporting Information, Tables S35S38). Therefore, the ${ }^{5} \mathbf{T S} \mathbf{1}_{\text {iso }, \mathrm{X}}$ energies are consistently higher than the lowest energy $\mathrm{OH}$ or $\mathrm{X}$ rebound barriers shown in Figure 5. As such, for the iron(III)-hydroxo complexes it appears unlikely an isomerization of the hydroxo intermediates will take place. Consequently, isomerization is not expected to play an important role in the reactivity profiles of these complexes. Full details of the isomerization structures and reactivity patterns with respect to the oxidant from Figure 2 are given in the Supporting Information.

\section{DISCUSSION}

As shown in this work, the chemoselectivity of ethylbenzene activation by $\left[\mathrm{Fe}^{\mathrm{IV}}(\mathrm{O})(\mathrm{TPA}) \mathrm{X}\right]^{+}$with $\mathrm{X}=\mathrm{NO}_{2}{ }^{-}, \mathrm{N}_{3}{ }^{-}$, or $\mathrm{Cl}^{-}$ varies with the nature of the cis-ligand. In particular, the complex with $\mathrm{X}=\mathrm{NO}_{2}^{-}$gives dominant 1-phenylethanol products, whereas with $\mathrm{X}=\mathrm{N}_{3}{ }^{-}$we expect azide transfer to the substrate. Bollinger and co-workers ${ }^{16}$ experimentally studied an engineered SyrB2 structure for the $\mathrm{N}_{3}$ and $\mathrm{NO}_{2}$ transfer to substrates. Interestingly, this bioengineered halogenase gives larger amounts of $\mathrm{NO}_{2}$ than $\mathrm{N}_{3}$ transfer. The difference in reactivity between our biomimetic model and the engineered SyrB2 structure most probably stems from differences in substrate-binding position. Thus, earlier work on nonheme iron halogenases and hydroxylases ${ }^{33 \mathrm{~b}, 44}$ showed that substrate positioning determines the regio- and chemoselectivity of substrate activation, and engineering the active site of a protein can result in changes of product distributions. ${ }^{45}$ In order to understand these distinct differences in reactivity patterns, we did a detailed analysis of the electronic and thermochemical properties of reactants and intermediates and devised a valence bond model for group-transfer reactivity by iron(IV)-oxo complexes.

Previously ${ }^{17 \mathrm{e}}$ it was proposed that efficient halogenation by nonheme iron biomimetic models requires an iron(III)hydroxo(halide) intermediate with a long lifetime. The lifetime of radical intermediates, like $\mathbf{I} \mathbf{1}, \mathbf{I} \mathbf{2}$, and $\mathbf{I} \mathbf{1} *$ structures above, is dependent on the electron-transfer pathways that occur in the $\mathrm{OH}$ versus $\mathrm{X}$ rebound steps. For instance, in heme enzymes, such as the cytochromes P450, a hydroxylation reaction by compound I (the iron(IV)-oxo heme cation radical) gives a rate-determining hydrogen atom abstraction typically followed 
by a barrierless rebound on the doublet spin state and a small rebound barrier on the high-spin state. ${ }^{46,47}$ As such, the radical intermediate in the P450s has a short lifetime and often rebound the oxygen-containing group to the substrate. By contrast, nonheme iron hydroxylases and their biomimetic models tend to have higher rebound barriers and sometimes even give nonrebound pathways where the radical dissipates from the reaction center. ${ }^{48}$ This is the result of differences in electronic configuration of heme and nonheme complexes of these radical intermediates. As nonheme iron intermediates often are in a high-spin states with five unpaired electrons in the metal 3d-system coupled to a substrate radical, this implies an electron transfer from substrate into the lowest $3 \mathrm{~d}$ iron orbital. In this work, we find several reaction pathways for rebound steps that are virtually barrierless, e.g., azide transfer from ${ }^{5} \mathrm{I1}_{\mathrm{N} 3}$ (Figure 5); consequently, some pathways are naturally low in energy and do not require a radical intermediate with long lifetime. How and what determines the product distributions and particularly how the electron transfer is affected by the structure and ligands of the complex as will be discussed in the next few sections, where we analyze the thermochemistry and electronic properties for the rebound ( $\mathrm{OH}$ vs $\mathrm{X})$ in detail.

Thermochemical Analysis of the Hydrogen Atom Abstraction. In order to compare the catalytic abilities of $\left[\mathrm{Fe}^{\mathrm{IV}}(\mathrm{O})(\mathrm{TPA}) \mathrm{X}\right]^{+}, \mathrm{X}=\mathrm{NO}_{2}^{-} / \mathrm{N}_{3}^{-} / \mathrm{Cl}^{-}$, we started with a thermochemical analysis of the hydrogen atom abstraction step. Thus, the hydrogen atom abstraction by $\left[\mathrm{Fe}^{\mathrm{IV}}(\mathrm{O})(\mathrm{TPA})\right.$ $\mathrm{X}]^{+}$from substrate $(\mathrm{SubH})$ can be described by eq 1 .

$$
\begin{aligned}
& {\left[\mathrm{Fe}^{\mathrm{IV}}(\mathrm{O})(\mathrm{TPA}) \mathrm{X}\right]^{+}+\mathrm{SubH}} \\
& \quad \rightarrow\left[\mathrm{Fe}^{\mathrm{III}}(\mathrm{OH})(\mathrm{TPA}) \mathrm{X}\right]^{+}+\mathrm{Sub}^{\bullet}
\end{aligned}
$$

The reaction enthalpy $\left(\Delta H_{\mathrm{rp}, \mathrm{HAT}}\right)$ for eq 1 is equal to the difference in bond dissociation energy (BDE) of the $\mathrm{C}-\mathrm{H}$ bond of the substrate (as defined in eq 2) and the $\mathrm{O}-\mathrm{H}$ bond of the iron(III)-hydroxo complex (as defined in eq 3 ); see eq $4 .^{43,49}$

$$
\begin{aligned}
& \mathrm{SubH} \rightarrow \mathrm{Sub}^{\bullet} \mathrm{H}^{\bullet}-\mathrm{BDE}_{\mathrm{CH}} \\
& \quad\left[\mathrm{Fe}^{\mathrm{III}}(\mathrm{OH})(\mathrm{TPA}) \mathrm{X}\right]^{+} \\
& \quad \rightarrow\left[\mathrm{Fe}^{\mathrm{IV}}(\mathrm{O})(\mathrm{TPA}) \mathrm{X}\right]^{+}+\mathrm{H}^{\bullet}-\mathrm{BDE}_{\mathrm{OH}} \\
& \Delta H_{\mathrm{rp}, \mathrm{HAT}}=\mathrm{BDE}_{\mathrm{CH}}-\mathrm{BDE}_{\mathrm{OH}}
\end{aligned}
$$

We calculate a $\mathrm{BDE}_{\mathrm{CH}}$ of the $\alpha$-position of ethylbenzene $\left(\Delta E+\mathrm{ZPE}+E_{\text {solv }}\right)$ of $81.4 \mathrm{kcal} \mathrm{mol}^{-1}$, which is in good agreement with the experimentally reported value. ${ }^{29}$ Using eq $3, \mathrm{BDE}_{\mathrm{OH}}$ values of $81.5,81.7$, and $95.7 \mathrm{kcal} \mathrm{mol}^{-1}$ were obtained for $\mathbf{1}_{\mathrm{NO} 2}, \mathbf{1}_{\mathrm{N} 3}$, and $\mathbf{1}_{\mathrm{Cl}}$, respectively. As such, we predict a $\Delta H_{\mathrm{rp}}$ for the reaction of ethylbenzene with $\mathbf{1}_{\mathrm{NO} 2}$ of $0.1 \mathrm{kcal} \mathrm{mol}^{-1}$, which agrees well with the driving force for the hydrogen atom abstraction seen in Figure 2. Similarly, a driving force of $0.3 \mathrm{kcal} \mathrm{mol}^{-1}$ is obtained from the difference in $\mathrm{BDE}_{\mathrm{CH}}$ and $\mathrm{BDE}_{\mathrm{OH}}\left(\mathbf{1}_{\mathrm{N} 3}\right)$. The potential energy landscape for the hydrogen atom abstraction, therefore, follows the expected ordering and thermochemistry due to differences in $\mathrm{BDE}_{\mathrm{OH}}$.

In the next stage, the reaction between $\left[\mathrm{Fe}^{\mathrm{III}}(\mathrm{OH})(\mathrm{TPA})\right.$ $\mathrm{X}^{+}$and $\mathrm{Sub}^{\bullet}$ was considered to lead to alcohol and X-grouptransfer processes. Scheme 4 gives the thermochemical predictions based on bond energies of the isolated $\left[\mathrm{Fe}^{\mathrm{III}}(\mathrm{OH})\right.$ -
(TPA) $\mathrm{X}^{+}$and substrate species of the bonds that are broken and formed in the process.

Scheme 4. Driving Forces for Bifurcation Pathways for $\mathrm{X}$ versus $\mathrm{OH}$ Transfer ${ }^{a}$
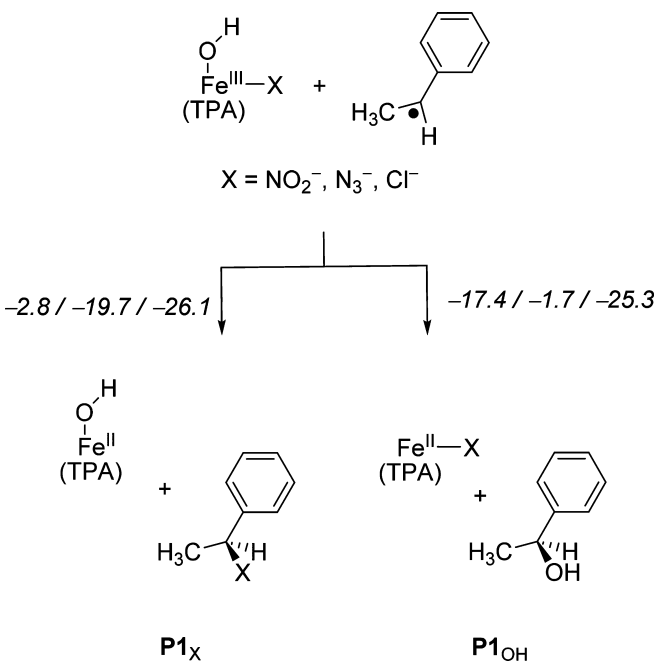

${ }^{a}$ Energies in $\mathrm{kcal} \mathrm{mol}^{-1}$.

Driving forces were calculated at UB3LYP/BS2//UB3LYP/ $\mathrm{BS} 1+\mathrm{ZPE}$, where the $\mathrm{Fe}-\mathrm{OH}$ and $\mathrm{Fe}-\mathrm{X}$ values refer to diabatic values only. The dissociation energies of SubX into $\mathrm{Sub}^{\bullet}+\mathrm{X}^{\bullet}$ were calculated for $\mathrm{X}=\mathrm{Cl}, \mathrm{N}_{3}$, and $\mathrm{NO}_{2}$, and values of $62.7,48.3$, and $39.6 \mathrm{kcal} \mathrm{mol}^{-1}$ were found. These values imply that if the binding strength of $\mathrm{X}$ to the metal center is the same for all three reactions then halogenation should be the most exothermic reaction mechanism and dominant over azidation and nitration.

We then looked into the binding strength of $\mathrm{X}$ and $\mathrm{OH}$ in the $\left[\mathrm{Fe}^{\mathrm{III}}(\mathrm{OH})(\mathrm{TPA}) \mathrm{X}\right]^{+}$complex. We find little variation in the $\mathrm{Fe}-\mathrm{X}$ bond strength for the three complexes, and values of $36.6(\mathrm{Cl}), 28.5\left(\mathrm{~N}_{3}\right)$, and $36.8\left(\mathrm{NO}_{2}\right) \mathrm{kcal} \mathrm{mol}^{-1}$ are calculated. By contrast, the $\mathrm{Fe}-\mathrm{OH}$ bond strength varies dramatically from $37.4 \mathrm{kcal} \mathrm{mol}^{-1}$ for $\mathrm{X}=\mathrm{Cl}$ to $54.4 \mathrm{kcal} \mathrm{mol}^{-1}$ for $\mathrm{X}=\mathrm{NO}_{2}$ and $70.0 \mathrm{kcal} \mathrm{mol}^{-1}$ for $\mathrm{X}=\mathrm{N}_{3}$. As a result of this, the azide pathway has a highly exothermic $\mathrm{N}_{3}$ transfer, whereas the energetics are reversed for $\mathrm{X}=\mathrm{NO}_{2}$, which gives preferential $\mathrm{OH}$ rebound. As follows from the calculated driving forces, for $\mathrm{X}=\mathrm{NO}_{2}$, the most exothermic reaction pathway is $\mathrm{OH}$ transfer to give the alcohol products $\left(\mathbf{P} 1_{\mathrm{OH}, \mathrm{NO} 2}\right)$ by $-17.4 \mathrm{kcal} \mathrm{mol}^{-1}$. By contrast, the $\mathrm{NO}_{2}$ transfer only releases $-2.8 \mathrm{kcal} \mathrm{mol}^{-1}$ in energy and hence will be thermodynamically less likely to happen than $\mathrm{OH}$ rebound. Indeed, that is seen from the relative barrier heights and exothermicities in Figure 5 above.

Interestingly, for $\mathrm{X}=\mathrm{N}_{3}$, the most favorable reaction pathway is $\mathrm{N}_{3}$ rebound to form azide product $\mathbf{P 1}_{\mathrm{X}, \mathrm{N} 3}$ by -19.7 $\mathrm{kcal} \mathrm{mol}^{-1}$. By comparison, the $\mathrm{OH}$ rebound is much less exothermic with a value of $-1.7 \mathrm{kcal} \mathrm{mol}^{-1}$. These exothermicities are in excellent agreement with the density functional theory (DFT) calculations that predict a chemoselective $\mathrm{N}_{3}$ rebound over $\mathrm{OH}$ rebound. Nevertheless, since the product distributions are strongly dependent on the binding strength of the ligand $\mathrm{X}$ to the metal center, different product distributions may be expected from alternative oxidants. Indeed, the bioengineered SyrB2 system of Bollinger 
(a)

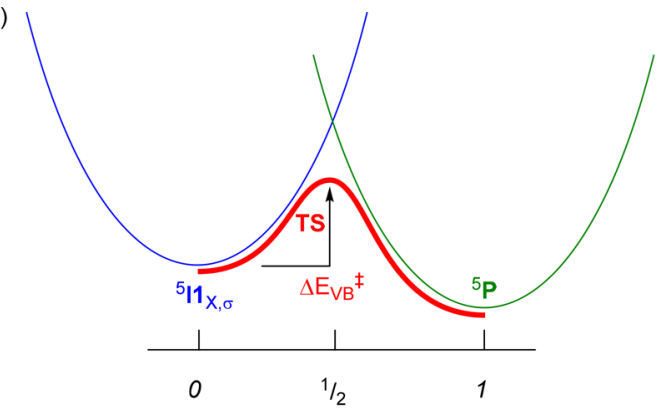

(b)

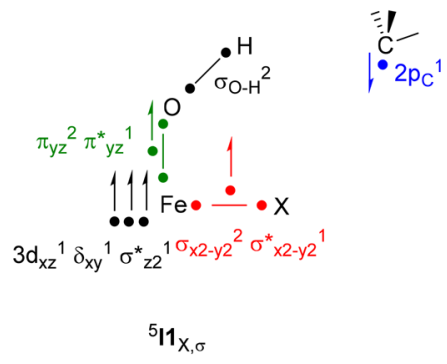

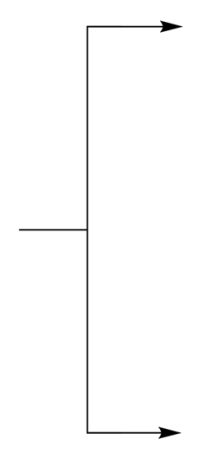
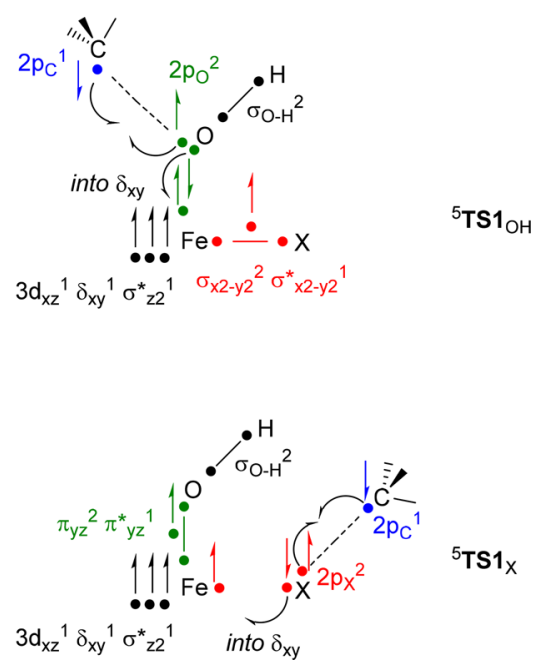

Figure 7. (a) Two-parabola curve crossing diagram for the prediction of barrier heights for reactions from VB principles. (b) Bond-breaking and bond-forming patterns during the $\mathrm{OH}$ and $\mathrm{X}$ transfer barriers. Dots represent electrons and a line separating two dots a molecular orbital with two electrons.

et al. $^{16}$ gave dominant nitration and less azidation in contrast to the product distributions of the TPA system discussed here. On top of that, there may be effects of the protein surrounding and second coordination effects in the protein that restrict some pathways.

To understand the ordering of the $\mathbf{T S}_{\mathrm{X}}$ versus $\mathbf{T} \mathbf{S}_{\mathrm{OH}}$ barriers for $\mathrm{X}=\mathrm{NO}_{2}$ and $\mathrm{X}=\mathrm{N}_{3}$, we did a detailed orbital analysis and devised a valence bond mechanism for the bifurcation pathways.

Valence Bond Rationalization of Group Transfer versus Hydroxyl Rebound. Previously, we used valence bond modeling to rationalize the origin of the rate constant of hydrogen atom abstraction reactions by heme and nonheme iron oxidants. ${ }^{46,50}$

The work proposed a linear correlation between the strength of the $\mathrm{C}-\mathrm{H}$ of the substrate that is broken $\left(\mathrm{BDE}_{\mathrm{CH}}\right)$ and the free energy of activation of the hydrogen atom abstraction reaction. In a similar vein, a correlation with the strength of the $\mathrm{O}-\mathrm{H}$ bond that is formed of a series of metal-oxo oxidants for propene hydroxylation with the free energy of hydrogen atom abstraction was found. ${ }^{50}$ Furthermore, the VB models predicted the origin of chemoselectivity patterns and explained bifurcation patterns. $^{51}$

Figure 7 displays a valence bond diagram that describes the bifurcation patterns and electronic changes during the $\mathrm{OH}$ and $\mathrm{X}$ rebound processes from ${ }^{5} \mathbf{I}_{\mathrm{X}, \sigma}$. The top part of Figure 7 gives the valence bond curves for ${ }^{5} \mathbf{I} \mathbf{1}_{\mathrm{X}, \sigma}$ and the product (either ${ }^{5} \mathbf{P} \mathbf{1}_{\mathrm{OH}}$ or $\left.{ }^{5} \mathbf{P} \mathbf{1}_{\mathrm{X}}\right)$ described as parabolic functions that cross at a reaction coordinate of $x=1 / 2 .{ }^{52}$

It was shown that the barrier height $\left(\Delta E_{\mathrm{VB}}\right)$ can be predicted from the energy difference $\left(E_{\mathrm{FC}}\right)$ between the two curves in $x=0$, i.e., the geometry of ${ }^{5} \mathbf{I}_{\mathrm{X}, \sigma}$, and the driving force for the reaction from ${ }^{5} \mathbf{I} \mathbf{1}_{\mathrm{X}, \sigma}$ to products $\left(\Delta E_{\mathrm{rp}}\right)$, eq 5 . This equation contains the resonance energy $\mathrm{B}$ to account for the geometric and electronic changes from reactants to transition state and is generally estimated as the weakest bond that is either broken or formed. ${ }^{46}$

$$
\Delta E_{\mathrm{VB}}^{\ddagger}=\frac{1}{4} E_{\mathrm{FC}}+\frac{3}{4} \Delta E_{\mathrm{rp}}+\mathrm{B}
$$

Thus, the driving force $\Delta E_{\mathrm{rp}}$ is taken as the energy for the breaking of the $\mathrm{Fe}-\mathrm{OH} / \mathrm{Fe}-\mathrm{X}$ on the one hand and the formation of the $\mathrm{C}-\mathrm{OH} / \mathrm{C}-\mathrm{X}$ on the other hand. Adiabatic bond dissociation energies for the $\mathrm{C}-\mathrm{OH} / \mathrm{C}-\mathrm{X}$ bond in 1phenylethanol and 1-phenyl-chloroethane of 71.7 and $62.7 \mathrm{kcal}$ $\mathrm{mol}^{-1}$ were calculated.

The value $E_{\mathrm{FC}}$ is dependent on the bonds that are broken and formed in the transition states. Figure $7 \mathrm{~b}$ shows the electron migration and bond breaking/forming patterns in ${ }^{5} \mathrm{TS} \mathbf{1}_{\mathrm{OH}}$ and ${ }^{5} \mathrm{TS} \mathbf{1}_{\mathrm{X}}$ as a comparison. In particular, the transfer of the $\mathrm{OH}$ group (rebound) to the radical leads to the breaking of the 3-electron $\pi_{y z} / \pi^{*}{ }_{y z}$ pair of orbitals into atomic orbitals. One of these electrons pairs up with the radical on the substrate to form the $\mathrm{C}-\mathrm{O}$ bond, while the other two electrons stay on iron: one in the $3 \mathrm{~d}_{y z}$ atomic orbital and one pairs up with the $\delta_{x y}$ electron. Therefore, the $\mathrm{E}_{\mathrm{FC}}$ for $\mathrm{OH}$ rebound will be proportional to the energy to break the $\pi_{y z} / \pi^{*}{ }_{y z}$ orbitals $\left(\mathrm{E}_{\pi / \pi^{*} y z}\right)$, the energy to promote an electron from $\pi_{y z}$ to $\delta_{x y}$ and the energy to form the $\mathrm{C}-\mathrm{O}$ bond $\left(\mathrm{BDE}_{\mathrm{CO}}\right)$.

Based on the orbital energy levels in $\left[\mathrm{Fe}^{\mathrm{III}}(\mathrm{OH})(\mathrm{TPA})\right.$ $\left.\mathrm{NO}_{2}\right]^{+}$we determined values for the $\mathrm{E}_{\pi / \pi^{*} y z}$ and $\mathrm{E}_{\sigma / \sigma^{*} x 2-y 2}$ as well as the excitation energies that happen during $\mathrm{X} / \mathrm{OH}$ transfer. With the $\Delta E_{\mathrm{rp}}$ values for these processes from Scheme 4 , we determine a $\mathrm{VB}$ predicted $\mathrm{OH}$ rebound barrier of $\Delta E_{\mathrm{VB}, \mathrm{OH}}{ }^{\ddagger}=5.6 \mathrm{kcal} \mathrm{mol}^{-1}$, which compares well with the DFT-calculated rebound barrier from Figure 5. By contrast, an $\mathrm{NO}_{2}$-rebound barrier of $\Delta E_{\mathrm{VB}, \mathrm{NO} 2}{ }^{\ddagger}=21.6 \mathrm{kcal} \mathrm{mol}^{-1}$ is predicted from empirical orbital and thermochemical values. 
Indeed, the orbital changes predict preferential $\mathrm{OH}$ rebound over $\mathrm{NO}_{2}$ rebound as also observed from the full DFT studies reported above.

In a similar vein, we estimated the $E_{\pi / \pi^{*} y z}$ and $E_{\sigma / \sigma^{*} x 2-y 2}$ values from the molecular orbitals of the $\left[\mathrm{Fe}^{\mathrm{III}}(\mathrm{OH})(\mathrm{TPA})-\right.$ $\left.\mathrm{N}_{3}\right]^{+}$complex and in combination with the $\Delta E_{\mathrm{rp}}$ values from Scheme 4 predicted rebound barriers of $\Delta E_{\mathrm{VB}, \mathrm{OH}}{ }^{\ddagger}=6.2 \mathrm{kcal}$ $\mathrm{mol}^{-1}$ and $\Delta E_{\mathrm{VB}, \mathrm{N} 3}{ }^{\ddagger}=4.6 \mathrm{kcal} \mathrm{mol}^{-1}$. Therefore, the nonheme iron complex with $\mathrm{N}_{3}$ in the cis-position should preferentially give $\mathrm{N}_{3}$ rebound over $\mathrm{OH}$ rebound as indeed observed from the DFT calculations depicted above. Clearly, the chemoselectivity switch from substrate hydroxylation for $\left[\mathrm{Fe}^{\mathrm{IV}}(\mathrm{O})\right.$ $\left.(\mathrm{TPA}) \mathrm{NO}_{2}\right]^{+}$to azidation for $\left[\mathrm{Fe}^{\mathrm{IV}}(\mathrm{O})(\mathrm{TPA}) \mathrm{N}_{3}\right]^{+}$results from molecular orbital changes. In particular, the $\pi_{y z} / \pi^{*}{ }_{y z}$ energy gap in $\left[\mathrm{Fe}^{\mathrm{III}}(\mathrm{OH})(\mathrm{TPA}) \mathrm{X}\right]^{+}$widens from $80.0 \mathrm{kcal}$ $\mathrm{mol}^{-1}$ for $\mathrm{X}=\mathrm{NO}_{2}$ to $108.5 \mathrm{kcal} \mathrm{mol}^{-1}$ for $\mathrm{X}=\mathrm{N}_{3}$. At the same time, the strong electron-withdrawing substituents affect the energy levels of the $\sigma_{x 2-y 2}$ and $\sigma_{x 2-y 2}^{*}$ orbitals, and their energy gap is decreased from $103.0 \mathrm{kcal} \mathrm{mol}^{-1}$ for $\mathrm{X}=\mathrm{NO}_{2}$ to 76.9 $\mathrm{kcal} \mathrm{mol}^{-1}$ for $\mathrm{X}=\mathrm{N}_{3}$. The combination of the widening of the $\pi_{y z} / \pi^{*}{ }_{y z}$ energy gap with the decrease of the $\sigma_{x 2-y 2} / \sigma^{*}{ }_{x 2-y 2}$ energy gap leads to a chemoselectivity change for substrate hydroxylation to azidation.

The valence-bond model indicates, therefore, that an electron-donating cis-substituent, such as $\mathrm{N}_{3}{ }^{-}$, will affect the orbital energies of the $\pi_{y z} / \pi^{*}{ }_{y z}$ and $\sigma_{x 2-y 2} / \sigma^{*}{ }_{x 2--y 2}$ couples and, therefore, favor ligand transfer. This may be the reason that in nature nonheme iron dioxygenases usually have a 2-His/1-Asp facial ligand coordination system with the carboxylate located in the cis-position. Consequently, iron(IV)-oxo complexes with a carboxylate group in the cis-position may be more reactive in ligand-transfer reactions than the pyridine-type ligand system with four coordinating nitrogen atoms. However, future studies will need to establish this.

\section{CONCLUSIONS}

In this work, we present a detailed and in-depth study into the preference for group-transfer versus hydroxylation of ethylbenzene by $\left[\mathrm{Fe}^{\mathrm{IV}}(\mathrm{O})(\mathrm{TPA}) \mathrm{X}\right]^{+}, \mathrm{X}=\mathrm{NO}_{2}{ }^{-}, \mathrm{N}_{3}^{-}$, or $\mathrm{Cl}^{-}$. A series of density functional theory calculations reveal mechanisms that start with hydrogen atom abstraction from substrate by the oxo group. Subsequent pathways for $\mathrm{OH} / \mathrm{X}$ isomerization, $\mathrm{OH}$ rebound, and $\mathrm{X}$-transfer were investigated and compared. The reaction mechanism proceeds via a multistate reactivity pattern with close-lying triplet and quintet spin states, whereby several electronically different pathways were considered for hydrogen atom abstraction via ${ }^{3,5} \sigma$ - and ${ }^{3,5} \pi$-pathways. The ordering and relative energies of these ${ }^{3,5} \sigma$ and ${ }^{3,5} \pi$-pathways are dependent on the electronic configuration of the metal center, i.e. its coordination environment, the electron-withdrawing and -donating abilities of the ligand, and the spin-state ordering. The same is true for the mechanism for isomerization of the $\mathrm{OH}$ and $\mathrm{X}$ groups, the $\mathrm{X}$-transfer, and $\mathrm{OH}$ rebound barrier heights, which change in ordering depending on subtle environmental perturbations. As such, we predict a variety of possible reaction pathways leading to a mixture of products for the complexes. The full reaction mechanism and the origin of the reactivity differences is explained with thermochemical models, valence bond diagrams and molecular orbital discussions. It is very well possible that an analogous reaction can be catalyzed by nonheme iron halogenases by supplying the system with $\mathrm{NO}_{2} / \mathrm{N}_{3}$ groups rather than halides. However, this will have to await further experimental verification. It would be interesting to see how nonheme iron halogenases and biomimetic models can perform these group-transfer reactions.

\section{ASSOCIATED CONTENT}

\section{Supporting Information}

The Supporting Information is available free of charge on the ACS Publications website at DOI: 10.1021/acscatal.8b01673.

Tables with absolute and relative energies, group spin densities and charges as well as Cartesian coordinates of all structures (PDF)

\section{AUTHOR INFORMATION}

\section{Corresponding Authors}

*E-mail: quesnem@cardiff.ac.uk.

*E-mail: ncborows@cyf-kr.edu.pl.

*E-mail: sam.devisser@manchester.ac.uk.

ORCID

Matthew G. Quesne: 0000-0001-5130-1266

Tomasz Borowski: 0000-0002-3450-3576

Sam P. de Visser: 0000-0002-2620-8788

Notes

The authors declare no competing financial interest.

\section{ACKNOWLEDGMENTS}

The BBSRC is acknowledged for a studentship for A.T. under Grant Code BB/J014478/1. The EU-COST Network Explicit Control Over Spin-states in Technology and Biochemistry (ECOSTBio, CM1305) is acknowledged for short-term scientific mission of MGQ. This research was supported in part by PL-Grid Infrastructure to TB.

\section{REFERENCES}

(1) (a) van Pee, K.-H. Biosynthesis of halogenated metabolites by bacteria. Annu. Rev. Microbiol. 1996, 50, 375-399. (b) Vaillancourt, F. H.; Yeh, E.; Vosburg, D. A.; Garneau-Tsodikova, S.; Walsh, C. T. Nature's inventory of halogenation catalysts: oxidative strategies predominate. Chem. Rev. 2006, 106, 3364-3378. (c) Stonik, V. A.; Fedorov, S. N. Marine low molecular weight natural products as potential cancer preventive compounds. Mar. Drugs 2014, 12, 636671

(2) (a) Gribble, G. W. Naturally occurring organohalogen compounds. Acc. Chem. Res. 1998, 31, 141-152. (b) Anderson, R. J. L.; Chapman, S. K. Molecular mechanisms of enzyme-catalysed halogenation. Mol. BioSyst. 2006, 2, 350-357. (c) Butler, A.; Sandy, M. Mechanistic considerations of halogenating enzymes. Nature 2009, $460,848-854$.

(3) See, e.g.: (a) Vilter, H. Peroxidases from Phaeophyceae: a vanadium (V)-dependent peroxidase from Ascophyllum nodosum. Phytochemistry 1984, 23, 1387-1390. (b) Dairi, T.; Nakano, T.; Aisaka, K.; Katsumata, R.; Hasegawa, M. Cloning and nucleotide sequence of the gene responsible for chlorination of tetracycline. Biosci., Biotechnol., Biochem. 1995, 59, 1099-1106. (c) Stone, K. L.; Behan, R. K.; Green, M. T. X-ray adsorption spectroscopy of chloroperoxidase compound I: insights into the reactive intermediate of P450 chemistry. Proc. Natl. Acad. Sci. U. S. A. 2005, 102, 1656316565. (d) Zampella, G.; Fantucci, P.; Pecoraro, V. L.; De Gioia, L. Reactivity of peroxo forms of vanadium haloperoxidase cofactor. A DFT investigation. J. Am. Chem. Soc. 2005, 127, 953-960. (e) van Pee, K.-H.; Dong, C.; Flecks, S.; Naismith, J.; Patallo, E. P.; Wage, T. Biological halogenation has moved far beyond haloperoxidases. Adv. Appl. Microbiol. 2006, 59, 127-157. (f) Conte, V.; Coletti, A.; Floris, B.; Licini, G.; Zonta, C. Mechanistic aspects of vanadium catalyzed oxidations with peroxides. Coord. Chem. Rev. 2011, 255, 2165-2177. 
(g) Senn, H. M. Insights into enzymatic halogenation from computational studies. Front. Chem. 2014, 2, 1-15.

(4) Neidig, M. L.; Brown, C. D.; Light, K. M.; Fujimori, D. G.; Nolan, E. M.; Price, J. C.; Barr, E. W.; Bollinger, J. M., Jr.; Krebs, C.; Walsh, C. T.; Solomon, E. I. CD and MCD of CytC3 and taurine dioxygenase: role of the facial triad in $\alpha$-KG dependent oxygenases. J. Am. Chem. Soc. 2007, 129, 14224-14231.

(5) (a) Solomon, E. I.; Brunold, T. C.; Davis, M. I.; Kemsley, J. N.; Lee, S. K.; Lehnert, N.; Neese, F.; Skulan, A. J.; Yang, Y. S.; Zhou, J. Geometric and electronic structure/function correlation in nonheme iron enzymes. Chem. Rev. 2000, 100, 235-349. (b) Costas, M.; Mehn, M. P.; Jensen, M. P.; Que, L., Jr Dioxygen activation at mononuclear iron active sites: enzymes, models, and intermediates. Chem. Rev. 2004, 104, 939-986. (c) Blasiak, L. C.; Drennan, C. L. Structural perspective on enzyme halogenation. Acc. Chem. Res. 2009, 42, 147155. (d) de Visser, S. P., Kumar, D., Eds. Iron-Containing Enzymes: Versatile Catalysts of Hydroxylation Reactions in Nature; Royal Society of Chemistry: Cambridge, 2011. (e) Buongiorno, D.; Straganz, G. D. Structure and function of atypically coordinated enzymatic mononuclear non-heme-Fe(II) centers. Coord. Chem. Rev. 2013, 257, 541563.

(6) Blasiak, L. C.; Vaillancourt, F. H.; Walsh, C. T.; Drennan, C. L. Crystal structure of the non-haem iron halogenase SyrB2 in syringomycin biosynthesis. Nature 2006, 440, 368-371.

(7) (a) Vaillancourt, F. H.; Yin, J.; Walsh, C. T. SyrB2 in syringomycin $\mathrm{E}$ biosynthesis is a nonheme FeII $\alpha$-ketoglutarate-and O2-dependent halogenase. Proc. Natl. Acad. Sci. U. S. A. 2005, 102, 10111-10116. (b) Galonic, D. P.; Barr, E. W.; Walsh, C. T.; Bollinger, J. M., Jr; Krebs, C. Two interconverting $\mathrm{Fe}(\mathrm{IV})$ intermediates in aliphatic chlorination by the halogenase CytC3. Nat. Chem. Biol. 2007, 3, 113-116. (c) Fullone, M. R.; Paiardini, A.; Miele, R.; Marsango, S.; Gross, D. C.; Omura, S.; Ros-Herrera, E.; Bonaccorsi di Patti, M. C.; Laganà, A.; Pascarella, S.; Grgurina, I. Insight into the structure-function relationship of the nonheme iron halogenases involved in the biosynthesis of 4-chlorothreonine thr3 from Streptomyces sp. OH-5093 and SyrB2 from Pseudomonas syringae pv. Syringae B301DR. FEBS J. 2012, 279, 4269-4282.

(8) (a) Que, L., Jr One motif-many different reactions. Nat. Struct. Biol. 2000, 7, 182-184. (b) Ryle, M. J.; Hausinger, R. P. Non-heme iron oxygenases. Curr. Opin. Chem. Biol. 2002, 6, 193-201. (c) Kryatov, S. V.; Rybak-Akimova, E. V.; Schindler, S. Kinetics and mechanisms of formation and reactivity of non-heme iron oxygen intermediates. Chem. Rev. 2005, 105, 2175-2226. (d) Bruijnincx, P. C. A.; van Koten, G.; Klein Gebbink, R. J. M. Mononuclear non-heme iron enzymes with the 2-His-1-carboxylate facial triad: recent developments in enzymology and modeling studies. Chem. Soc. Rev. 2008, 37, 2716-2744.

(9) (a) Borchardt, S. A.; Allain, E. J.; Michels, J. J.; Stearns, G. W.; Kelly, R. F.; McCoy, W. F. Reaction of acylated homoserine lactone bacterial signaling molecules with oxidized halogen antimicrobials. Appl. Environ. Microbiol. 2001, 67, 3174-3179. (b) Matthews, M. L.; Krest, C. M.; Barr, E. W.; Vaillancourt, F. H.; Walsh, C. T.; Green, M. T.; Krebs, C.; Bollinger, J. M., Jr Substrate-triggered formation and remarkable stability of the $\mathrm{C}-\mathrm{H}$ bond-cleaving chloroferryl intermediate in aliphatic halogenase, SyrB2. Biochemistry 2009, 48, 4331-4343.

(10) (a) Light, K. M.; Hangasky, J. A.; Knapp, M. J.; Solomon, E. I. Spectroscopic studies of the mononuclear non-heme $\mathrm{Fe}^{\mathrm{II}}$ enzyme FIH: Second-sphere contributions to reactivity. J. Am. Chem. Soc. 2013, 135, 9665-9674. (b) Pratter, S. M.; Ivkovic, J.; BirnerGruenberger, R.; Breinbauer, R.; Zangger, K.; Straganz, G. D. More than just a halogenase: modification of fatty acyl moieties by a trifunctional metal enzyme. ChemBioChem 2014, 15, 567-574.

(11) (a) Borowski, T.; Bassan, A.; Siegbahn, P. E. M. Mechanism of dioxygen activation in 2-oxoglutarate-dependent enzymes: A hybrid DFT study. Chem. - Eur. J. 2004, 10, 1031-1041. (b) Bollinger, J. M., Jr.; Price, J. C.; Hoffart, L. M.; Barr, E. W.; Krebs, C. Mechanism of taurine: $\alpha$-ketoglutarate (TauD) from Escherichia coli. Eur. J. Inorg. Chem. 2005, 2005, 4245-4254. (c) de Visser, S. P. Can the peroxosuccinate complex in the catalytic cycle of taurine $/ \alpha$ ketoglutarate dioxygenase (TauD) act as an alternative oxidant? Chem. Commun. 2007, 171-173. (d) Wójcik, A.; Radoń, M.; Borowski, T. Mechanism of $\mathrm{O}_{2}$ activation by $\alpha$-ketoglutarate dependent oxygenases revisited. A quantum chemical study. J. Phys. Chem. A 2016, 120, 1261-1274.

(12) (a) Godula, K.; Sames, D. CH bond functionalization in complex organic synthesis. Science 2006, 312, 67-72. (b) Herrerías, C. I.; Yao, X.; Li, Z.; Li, C.-J. Reactions of $\mathrm{C}-\mathrm{H}$ bonds in water. Chem. Rev. 2007, 107, 2546-2562.

(13) (a) Cho, S. H.; Kim, J. Y.; Kwak, J.; Chang, S. Recent advances in the transition metal-catalyzed twofold oxidative $\mathrm{C}-\mathrm{H}$ bond activation strategy $\mathrm{C}-\mathrm{C}$ and $\mathrm{C}-\mathrm{N}$ bond formation. Chem. Soc. Rev. 2011, 40, 5068-5083. (b) Surry, D. S.; Buchwald, S. L. Dialkylbiaryl phosphines in Pd-catalyzed amination: a user's guide. Chem. Sci. 2011, $2,27-50$.

(14) (a) Luo, Y. R. Comprehensive Handbook of Chemical Bond Energies; CRC Press: Boca Raton, FL, 2007. (b) Zheng, W. R.; Chen, Z. C.; Xu, W. X. DFT study on homolytic dissociation enthalpies of C-I bonds. Chin. J. Chem. Phys. 2013, 26, 541-548. (c) Viuf, C.; Bols, M. Radical azidination of benzylic positions with iodonium azide. Angew. Chem., Int. Ed. 2001, 40, 623-625.

(15) (a) Huang, X.; Groves, J. T. Taming azide radicals for catalytic C-H azidation. ACS Catal. 2016, 6, 751-759. (b) Liu, W.; Groves, J. $\mathrm{T}$. Manganese-catalyzed oxidative benzylic $\mathrm{C}-\mathrm{H}$ fluoride ions. Angew. Chem., Int. Ed. 2013, 52, 6024-6027. (c) Xu, L.; Mou, X. Q.; Chen, Z. M.; Wang, S. H. Copper-catalyzed intermolecular azidocyanation of aryl alkenes. Chem. Commun. 2014, 50, 10676-10679. (d) Wang, F.; Qi, X. X.; Liang, Z. L.; Chen, P. H.; Liu, G. S. Copper-catalyzed intermolecular trifluoromethylazidation of alkenes: Convenient access to $\mathrm{CF}_{3}$-containing alkyl azides. Angew. Chem., Int. Ed. 2014, 53, 18811886. (e) Yin, H.; Wang, T.; Jiao, N. Copper-catalyzed oxoazidation and alkoxyazidation of indoles. Org. Lett. 2014, 16, 2302-2305. (f) Sun, X.; Li, X. Y.; Song, S.; Zhu, Y. C.; Liang, Y. F.; Jiao, N. Mncatalyzed highly efficient aerobic oxidative hydroxyazidation of olefins: A direct approach to $\beta$-azido alcohols. J. Am. Chem. Soc. 2015, 137, 6059-6066. (g) Wang, Y.; Li, G.-X.; Yang, G.; He, G.; Chen, G. A visible-light-promoted radical reaction system for azidation and halogenation of tertiary aliphatic $\mathrm{C}-\mathrm{H}$ bonds. Chem. Sci. 2016, 7, 2679-2683.

(16) Matthews, M. L.; Chang, W.-c.; Layne, A. P.; Miles, L. A.; Krebs, C.; Bollinger, J. M., Jr Direct nitration and azidation of aliphatic carbons by an iron-dependent halogenase. Nat. Chem. Biol. 2014, 10, 209-215.

(17) (a) Rohde, J. U.; In, J. H.; Lim, M. H.; Brennessel, W. W.; Bukowski, M. R.; Stubna, A.; Münck, E.; Nam, W.; Que, L., Jr Crystallographic and spectroscopic characterization of a nonheme $\mathrm{Fe}$ $(I V)=O$ complex. Science 2003, 299, 1037-1039. (b) Sastri, C. V.; Lee, J.; Oh, K.; Lee, Y. J.; Jackson, T. A.; Ray, K.; Hirao, H.; Shin, W.; Halfen, J. A.; Kim, J.; Que, L., Jr; Shaik, S.; Nam, W. Axial ligand tuning of a nonheme iron (IV)-oxo unit for hydrogen atom abstraction. Proc. Natl. Acad. Sci. U. S. A. 2007, 104, 19181-19186. (c) Podgorsek, A.; Zupan, M.; Iskra, J. Oxidative halogenation with "green" oxidants: oxygen and hydrogen peroxide. Angew. Chem., Int. Ed. 2009, 48, 8424-8450. (d) Comba, P.; Wunderlich, S. Ironcatalyzed halogenation of alkanes: Modeling of nonheme halogenases by experiment and DFT calculations. Chem. - Eur. J. 2010, 16, 72937299. (e) Puri, M.; Biswas, A. N.; Fan, R.; Guo, Y.; Que, L., Jr. Modeling non-heme iron halogenases: high-spin oxoiron(IV)-halide complexes that halogenate $\mathrm{C}-\mathrm{H}$ bonds. J. Am. Chem. Soc. 2016, 138, $2484-2487$.

(18) (a) Kojima, T.; Leising, R. A.; Yan, S.; Que, L., Jr Alkane functionalization at nonheme iron centers. Stoichiometric transfer of metal-bond ligands to alkane. J. Am. Chem. Soc. 1993, 115, 1132811335. (b) Company, A.; Feng, Y.; Guell, M.; Ribas, X.; Luis, J. M.; Que, L., Jr; Costas, M. Olefin-dependent discrimination between two nonheme $\mathrm{HO}-\mathrm{Fe}^{\mathrm{V}}=\mathrm{O}$ tautomeric species in catalytic $\mathrm{H}_{2} \mathrm{O}_{2}$ epoxidations. Chem. - Eur. J. 2009, 15, 3359-3362. (c) Makhlynets, O. V.; Das, P.; Taktak, S.; Flook, M.; Mas-Balleste, R.; Rybak- 
Akimova, E. V.; Que, L., Jr Iron-promoted ortho-and/or ipsohydroxylation of benzoic acids with $\mathrm{H}_{2} \mathrm{O}_{2}$. Chem. - Eur. J. 2009, 15, 13171-13180. (d) Lyakin, O. Y.; Bryliakov, K. P.; Britovsek, G. J.; Talsi, E. P. EPR spectroscopic trapping of the active species of nonheme iron-catalyzed oxidation. J. Am. Chem. Soc. 2009, 131, 10798-10799. (e) Jastrzebski, R.; van den Berg, E. J.; Weckhuysen, B. M.; Bruijnincx, P. C. A. Sustainable production of dimethyl adipate by non-heme iron(II) catalyzed oxidative cleavage of catechol. Catal. Sci. Technol. 2015, 5, 2103-2109.

(19) (a) Quesne, M. G.; de Visser, S. P. Regioselectivity of substrate hydroxylation verus halogenation by a nonheme iron (IV)-oxo complex: possibility of rearrangement pathways. JBIC, J. Biol. Inorg. Chem. 2012, 17, 841-852. (b) Borowski, T.; Noack, H.; Radoń, M.; Zych, K.; Siegbahn, P. E. M. Mechanism of selective halogenation by SyrB2: a computational study. J. Am. Chem. Soc. 2010, 132, 1288712898. (c) Srnec, M.; Solomon, E. I. Frontier molecular orbital contributions to chlorination versus hydroxylation selectivity in the non-heme iron halogenase SyrB2. J. Am. Chem. Soc. 2017, 139, 23962407.

(20) (a) de Visser, S. P.; Nam, W. The effect and influence of cisligands on the electronic and oxidizing properties of nonheme oxoiron biomimetics. A density functional study. J. Phys. Chem. A 2008, 112, 12887-12895. (b) Jastrzebski, R.; Quesne, M. G.; Weckhuysen, B. M.; de Visser, S. P.; Bruijnincx, P. C. A. Experimental and computational evidence for the mechanism of intradiol catechol dioxygenation by non-heme iron(III) complexes. Chem. - Eur. J. 2014, $20,15686-15691$.

(21) Gaussian 09, revision C.01: Frisch, M. J.; Trucks, G. W.; Schlegel, H. B.; Scuseria, G. E.; Robb, M. A.; Cheeseman, J. R.; Scalmani, G.; Barone, V.; Mennucci, B.; Petersson, G. A.; Nakatsuji, H.; Caricato, M.; Li, X.; Hratchian, H. P.; Izmaylov, A. F.; Bloino, J.; Zheng, G.; Sonnenberg, J. L.; Hada, M.; Ehara, M.; Toyota, K.; Fukuda, R.; Hasegawa, J.; Ishida, M.; Nakajima, T.; Honda, Y.; Kitao, O.; Nakai, H.; Vreven, T.; Montgomery, J. A., Jr; Peralta, J. E.; Ogliaro, F.; Bearpark, M.; Heyd, J. J.; Brothers, E.; Kudin, K. N.; Staroverov, V. N.; Keith, T.; Kobayashi, R.; Normand, J.; Raghavachari, K.; Rendell, A.; Burant, J. C.; Iyengar, S. S.; Tomasi, J.; Cossi, M.; Rega, N.; Millam, J. M.; Klene, M.; Knox, J. E.; Cross, J. B.; Bakken, V.; Adamo, C.; Jaramillo, J.; Gomperts, R.; Stratmann, R. E.; Yazyev, O.; Austin, A. J.; Cammi, R.; Pomelli, C.; Ochterski, J. W.; Martin, R. L.; Morokuma, K.; Zakrzewski, V. G.; Voth, G. A.; Salvador, P.; Dannenberg, J. J.; Dapprich, S.; Daniels, A. D.; Farkas, O.; For-esman, J. B.; Ortiz, J. V.; Cioslowski, J.; Fox, D. J. Gaussian, Inc.: Wallingford, CT, 2010.

(22) (a) Becke, A. D. Density-functional thermochemistry. III. The role of exact exchange. J. Chem. Phys. 1993, 98, 5648-5652. (b) Lee, C.; Yang, W.; Parr, R. G. Development of the Colle-Salvetti correlation-energy formula into a functional of the electron density. Phys. Rev. B: Condens. Matter Mater. Phys. 1988, 37, 785-789.

(23) (a) Becke, A. D. Density-functional exchange-energy approximation with correct asymptotic behavior. Phys. Rev. A: At., Mol., Opt. Phys. 1988, 38, 3098-3100. (b) Perdew, J. P. Densityfunctional approximation for the correlation energy of the inhomogeneous electron gas. Phys. Rev. B: Condens. Matter Mater. Phys. 1986, 33, 8822-8824.

(24) Tao, J.; Perdew, J. P.; Staroverov, V. N.; Scuseria, G. E. Climbing the density functional ladder: Nonempirical metalgeneralized gradient approximation designed for molecules and solids. Phys. Rev. Lett. 2003, 91, 146401.

(25) (a) Zhao, Y.; Truhlar, D. G. The M06 suite of density functionals for main group thermochemistry, thermochemical kinetics, noncovalent interactions, excited states, and transition elements: two new functionals and systematic testing of four M06class functionals and 12 other functionals. Theor. Chem. Acc. 2008, 120, 215-241. (b) Zhao, Y.; Truhlar, D. G. Density functionals with broad applicability in chemistry. Acc. Chem. Res. 2008, 41, 157-167.

(26) Hay, P. J.; Wadt, W. R. Ab initio effective core potentials for molecular calculations. Potentials for the transition metal atoms $\mathrm{Sc}$ to Hg. J. Chem. Phys. 1985, 82, 270-283.
(27) Grimme, S.; Antony, J.; Ehrlich, S.; Krieg, H. A consistent and accurate $\mathrm{ab}$ initio parametrization of density functional dispersion correction (DFT-D) for the 94 elements H-Pu. J. Chem. Phys. 2010, $132,154104$.

(28) de Visser, S. P. Trends in substrate hydroxylation reactions by heme and nonheme iron(IV)-oxo oxidants give correlations between intrinsic properties of the oxidant with barrier height. J. Am. Chem. Soc. 2010, 132, 1087-1097.

(29) Hunter, E. P.; Lias, S. G. NIST Chemistry Webbook, NIST Standard Reference Database, Number 69; Linstrom, P. J., Mallard, W. G., Eds.; National Institute of Standards and Technology: Gaithersburg MD, 2017; http://webbook.nist.gov (retrieved June 7, 2017).

(30) See, e.g.: Cantú Reinhard, F. G.; Barman, P.; Mukherjee, G.; Kumar, J.; Kumar, D.; Kumar, D.; Sastri, C. V.; de Visser, S. P. Ketoenol tautomerization triggers an electrophilic aldehyde deformylation reaction by a nonheme manganese(III)-peroxo complex. J. Am. Chem. Soc. 2017, 139, 18328-18338.

(31) (a) Sahu, S.; Widger, L. R.; Quesne, M. G.; de Visser, S. P.; Matsumura, H.; Moënne-Loccoz, P.; Siegler, M. A.; Goldberg, D. P. Secondary coordination sphere influence on the reactivity of nonheme iron(II) complexes: An experimental and DFT approach. J. Am. Chem. Soc. 2013, 135, 10590-10593. (b) Sahu, S.; Quesne, M. G.; Davies, C. G.; Dürr, M.; Ivanović-Burmazović, I.; Siegler, M. A.; Jameson, G. N. L.; de Visser, S. P.; Goldberg, D. P. Direct observation of a nonheme iron(IV)-oxo complex that mediates aromatic $\mathrm{C}-\mathrm{F}$ hydroxylation. J. Am. Chem. Soc. 2014, 136, 13542-13545.

(32) (a) Hirao, H.; Kumar, D.; Que, L., Jr; Shaik, S. Two-state reactivity in alkane hydroxylation by non-heme iron-oxo complexes. J. Am. Chem. Soc. 2006, 128, 8590-8606. (b) de Visser, S. P. Differences in and comparison of the catalytic properties of heme and non-heme enzymes with a central oxo-iron group. Angew. Chem., Int. Ed. 2006, 45, 1790-1793.

(33) (a) Galonić Fujimori, D.; Barr, E. W.; Matthews, M. L.; Koch, G. M.; Yonce, J. R.; Walsh, C. T.; Bollinger, J. M., Jr; Krebs, C.; RiggsGelasco, P. J. Spectroscopic evidence for a high-spin $\mathrm{Br}$-Fe(IV)-oxo intermediate in the $\alpha$-ketoglutarate-dependent halogenase CytC3 from Streptomyces. J. Am. Chem. Soc. 2007, 129, 13408-13409. (b) Timmins, A.; Saint-André, M.; de Visser, S. P. Understanding how prolyl-4-hydroxylase structure steers a ferryl oxidant toward scission of a strong $\mathrm{C}-\mathrm{H}$ bond. J. Am. Chem. Soc. 2017, 139, 9855-9866. (c) Timmins, A.; de Visser, S. P. How are substrate binding and catalysis affected by mutating Glu127 and Arg161 in prolyl-4hydroxylase? A QM/MM and MD study. Front. Chem. 2017, 5, 1-13.

(34) (a) Que, L., Jr The road to non-heme oxoferryls and beyond. Acc. Chem. Res. 2007, 40, 493-500. (b) Nam, W. High-valent iron(IV)-oxo complexes of heme and non-heme ligands in oxygenation reactions. Acc. Chem. Res. 2007, 40, 522-531.

(35) Latifi, R.; Sainna, M. A.; Rybak-Akimova, E. V.; de Visser, S. P. Does hydrogen-bonding donation to manganese(IV)-oxo and iron(IV)-oxo oxidants affect the oxygen-atom transfer ability? Chem. - Eur. J. 2013, 19, 4058-4068.

(36) (a) Reiher, M.; Salomon, O.; Hess, B. A. Reparameterization of hybrid functionals based on energy differences of states of different multiplicity. Theor. Chem. Acc. 2001, 107, 48-55. (b) Ziegler, T.; Autschbach, J. Theoretical methods of potential use for studies of inorganic reaction mechanisms. Chem. Rev. 2005, 105, 2695-2722. (c) Swart, M. A change in the oxidation state of iron: scandium is not innocent. Chem. Commun. 2013, 49, 6650-6652.

(37) (a) Mas-Ballesté, R.; McDonald, A. R.; Reed, D.; Usharani, D.; Schyman, P.; Milko, P.; Shaik, S.; Que, L., Jr. Intramolecular gas-phase reactions of synthetic nonheme oxoiron(IV) Ions: Proximity and spinstate reactivity rules. Chem. - Eur. J. 2012, 18, 11747-11760. (b) Cantú Reinhard, F. G.; de Visser, S. P. Oxygen atom transfer using an iron(IV)-oxo embedded in a tetracyclic N-heterocyclic carbene system: How does the reactivity compare to cytochrome P450 compound I. Chem. - Eur. J. 2017, 23, 2935-2944. 
(38) Klapötke, T. M.; Deakyne, C. A.; Liebman, J. F. Paradigms and paradoxes: why is the electron affinity of azide radical, $\mathrm{N}_{3}$, so large? Struct. Chem. 2011, 22, 189-191.

(39) Rohde, J.-U.; Stubna, A.; Bominaar, E. L.; Münck, E.; Nam, W.; Que, L., Jr. Nonheme oxoiron(IV) complexes of tris(2pyridylmethyl)amine with cis-monoanionic Ligands. Inorg. Chem. 2006, 45, 6435-6445.

(40) (a) Hirao, H.; Kumar, D.; Thiel, W.; Shaik, S. Two states nd two more in the mechanism of hydroxylation and epoxidation by cytochrome p450. J. Am. Chem. Soc. 2005, 127, 13007-13018. (b) de Visser, S. P. What factors influence the ratio of $\mathrm{C}-\mathrm{H}$ hydroxylation versus $\mathrm{C}=\mathrm{C}$ epoxidation by a nonheme cytochrome $\mathrm{P} 450$ biomimetic? J. Am. Chem. Soc. 2006, 128, 15809-15818. (c) Ye, S.; Neese, F. Nonheme oxo-iron(IV) intermediates form an oxyl radical upon approaching the $\mathrm{C}-\mathrm{H}$ bond activation transition state. Proc. Natl. Acad. Sci. U. S. A. 2011, 108, 1228-1233. (d) Solomon, E. I.; Light, K. M.; Liu, L. V.; Srnec, M.; Wong, S. D. Geometric and electronic contributions to function in non-heme iron enzymes. Acc. Chem. Res. 2013, 46, 2725-2739. (e) Tang, H.; Guan, J.; Liu, H.; Huang, X. Analysis of an alternative to the $\mathrm{H}$-atom abstraction mechanism in methane $\mathrm{C}-\mathrm{H}$ bond activation by nonheme iron (IV)-oxo oxidants. Dalton Trans. 2013, 42, 10260-10270.

(41) (a) Ye, S.; Geng, C.-Y.; Shaik, S.; Neese, F. Electronic structure analysis of multistate reactivity in transition metal catalyzed reactions: the case of $\mathrm{C}-\mathrm{H}$ bond activation by non-heme iron (IV)-oxo cores. Phys. Chem. Chem. Phys. 2013, 15, 8017-8030. (b) Bernasconi, L.; Baerends, E. J. A frontier orbital study with ab initio molecular dynamics of the effect of solvation on chemical reactivity: solventinduced orbital control in $\mathrm{FeO}$-activated hydroxylation reactions. $J$. Am. Chem. Soc. 2013, 135, 8857-8867. (c) Hirao, H.; Li, F.; Que, L., Jr.; Morokuma, K. Theoretical study of the mechanism of oxoiron (IV) formation from $\mathrm{H}_{2} \mathrm{O}_{2}$ and a nonheme iron (II) complex: $\mathrm{O}-\mathrm{O}$ cleavage involving proton-coupled electron transfer. Inorg. Chem. 2011, 50, 6637-6648. (d) Tang, H.; Guan, J.; Zhang, L.; Liu, H.; Huang, $\mathrm{X}$. The effect of the axial ligand on distinct reaction tunneling for methane hydroxylation by nonheme iron (iv)-oxo complexes. Phys. Chem. Chem. Phys. 2012, 14, 12863-12874. (e) Zhao, J.; Sun, X.; Huang, X.; Li, J. Reaction mechanisms of methanol oxidation by $\mathrm{Fe}^{\mathrm{IV}} \mathrm{O}$ biomimetic complex. Int. J. Quantum Chem. 2016, 116, 692701. (f) Ansari, A.; Kaushik, A.; Rajaraman, G. Mechanistic insights on the ortho-hydroxylation of aromatic compounds by non-heme iron complex: A computational case study on the comparative oxidation ability of ferric-hydroperoxo and high-valent $\mathrm{Fe}^{\mathrm{N}}=\mathrm{O}$ and $\mathrm{Fe}^{\mathrm{V}}=\mathrm{O}$ intermediates. J. Am. Chem. Soc. 2013, 135, 4235-4249.

(42) (a) de Visser, S. P. Propene activation by the oxo-iron active species of taurine $/ \alpha$-ketoglutarate dioxygenase (TauD) enzyme. How does the catalysis compare to heme-enzymes? J. Am. Chem. Soc. 2006, 128, 9813-9824. (b) Decker, A.; Rohde, J.-U.; Klinker, E. J.; Wong, S. D.; Que, L., Jr.; Solomon, E. I. Spectroscopic and quantum chemical studies on low-spin $\mathrm{Fe}^{\mathrm{IV}} \mathrm{O}$ complexes: $\mathrm{Fe}-\mathrm{O}$ bonding and its contributions to reactivity. J. Am. Chem. Soc. 2007, 129, 1598315996.

(43) (a) de Visser, S. P.; Kumar, D.; Cohen, S.; Shacham, R.; Shaik, S. A predictive pattern of computed barriers for $\mathrm{C}-\mathrm{H}$ hydroxylation by compound I of cytochrome P450. J. Am. Chem. Soc. 2004, 126, 8362-8363. (b) Ji, L.; Faponle, A. S.; Quesne, M. G.; Sainna, M. A.; Zhang, J.; Franke, A.; Kumar, D.; van Eldik, R.; Liu, W.; de Visser, S. P. Drug metabolism by cytochrome P450 enzymes: what distinguishes the pathway leading to substrate hydroxylation over desaturation? Chem. - Eur. J. 2015, 21, 9083-9092.

(44) Matthews, M. L.; Neumann, C. S.; Miles, L. A.; Grove, T. L.; Booker, S. J.; Krebs, C.; Walsh, C. T.; Bollinger, J. M., Jr Substrate positioning controls the partition between halogenation and hydroxylation in the aliphatic halogenase, SyrB2. Proc. Natl. Acad. Sci. U. S. A. 2009, 106, 17723-17728.

(45) Pratter, S. M.; Konstantinovics, C.; DiGiuro, C. L. M.; Leitner, E.; Kumar, D.; de Visser, S. P.; Grogan, G.; Straganz, G. D. Inversion of enantio-selectivity of a mononuclear non-heme iron(II)-dependent hydroxylase by tuning the interplay of metal-center geometry and protein structure. Angew. Chem., Int. Ed. 2013, 52, 9677-9681.

(46) Shaik, S.; Kumar, D.; de Visser, S. P. A valence bond modeling of trends in hydrogen abstraction barriers and transition states of hydroxylation reactions catalyzed by cytochrome P450 enzymes. J. Am. Chem. Soc. 2008, 130, 10128-10140.

(47) (a) Shaik, S.; Cohen, S.; de Visser, S. P.; Sharma, P. K.; Kumar, D.; Kozuch, S.; Ogliaro, F.; Danovich, D. The "rebound controversy": An overview and theoretical modeling of the rebound step in $\mathrm{C}-\mathrm{H}$ hydroxylation by cytochrome P450. Eur. J. Inorg. Chem. 2004, 2004, 207-226. (b) Li, X.-X.; Postils, V.; Sun, W.; Faponle, A. S.; Solà; Wang, Y.; Nam, W.; de Visser, S. P. Reactivity patterns of (protonated) Compound II and Compound I of Cytochrome P450: Which is the better oxidant? Chem. - Eur. J. 2017, 23, 6406-6418.

(48) Cho, K.-B.; Hirao, H.; Shaik, S.; Nam, W. To rebound or dissociate? This is the mechanistic question in $\mathrm{C}-\mathrm{H}$ hydroxylation by heme and nonheme metal-oxo complexes. Chem. Soc. Rev. 2016, 45, $1197-1210$

(49) (a) Bordwell, F. G.; Cheng, J.-P. Substituent effects on the phenoxyl radicals and the acidities of phenoxyl radical cations. J. Am. Chem. Soc. 1991, 113, 1736-1743. (b) Mayer, J. M. Hydrogen atom abstraction by metal- oxo complexes: Understanding the analogy with organic radical reactions. Acc. Chem. Res. 1998, 31, 441-450.

(50) Latifi, R.; Bagherzadeh, M.; de Visser, S. P. Origin of the correlation of the rate constant of substrate hydroxylation by nonheme iron(IV)-oxo complexes with the bond-dissociation energy of $\mathrm{C}-\mathrm{H}$ bond of the substrate. Chem. - Eur. J. 2009, 15, 6651-6662.

(51) (a) Kumar, S.; Faponle, A. S.; Barman, P.; Vardhaman, A. K.; Sastri, C. V.; Kumar, D.; de Visser, S. P. Long-range electron transfer triggers mechanistic differences between iron(IV)-oxo and iron (IV)imido oxidants. J. Am. Chem. Soc. 2014, 136, 17102-17115. (b) Hernández-Ortega, A.; Quesne, M. G.; Bui, S.; Heyes, D. J.; Steiner, R. A.; Scrutton, N. S.; de Visser, S. P. Catalytic mechanism of cofactor-free deoxygenases and how they circumvent spin-forbidden oxygenation of their substrates. J. Am. Chem. Soc. 2015, 137, 74747487. (c) Faponle, A. S.; Quesne, M. G.; de Visser, S. P. Origin of the regioselective fatty-acid hydroxylation versus decarboxylation by a cytochrome peroxygenase: What drive the reaction to biofuels production? Chem. - Eur. J. 2016, 22, 5478-5483. (d) Quesne, M. G.; Senthilnathan, D.; Singh, D.; Kumar, D.; Maldivi, P.; Sorokin, A. B.; de Visser, S. P. Origin of the enhanced reactivity of $\mu$-nitridobridged diiron (IV)-oxo porphyrinoid complexes over cytochrome P450 Compound I. ACS Catal. 2016, 6, 2230-2243. (e) Yang, T.; Quesne, M. G.; Neu, H. M.; Cantú Reinhard, F. G.; Goldberg, D. P.; de Visser, S. P. Singlet versus triplet reactivity in an $\mathrm{Mn}(\mathrm{V})-$ oxo species: Testing theoretical predictions against experimental evidence. J. Am. Chem. Soc. 2016, 138, 12375-12386.

(52) (a) Sainna, M. A.; Kumar, S.; Kumar, D.; Fornarini, S.; Crestoni, M. E.; de Visser, S. P. A comprehensive test set of epoxidation rate constants for iron (IV)-oxo porphyrin cation radical complexes. Chem. Sci. 2015, 6, 1516-1529. (b) Barman, P.; Upadhyay, P.; Faponle, A. S.; Kumar, J.; Nag, S. S.; Kumar, D.; Sastri, C. V.; de Visser, S. P. Deformylation reaction by a nonheme manganese (III) - peroxo complex via initial hydrogen-atom abstraction. Angew. Chem., Int. Ed. 2016, 55, 11091-11095. (c) Cantú Reinhard, F. G.; Sainna, M. A.; Upadhyay, P.; Balan, G. A.; Kumar, D.; Fornarini, S.; Crestoni, M. E.; de Visser, S. P. A systematic account on aromatic hydroxylation by a cytochrome $\mathrm{P} 450$ model compound I: A low-pressure mass spectrometry and computational study. Chem. Eur. J. 2016, 22, 18608-18619. 